Todos os esforços foram feitos para contactar com os detentores dos direitos das imagens. Em caso de omissão, faremos todos os ajustes possíveis na primeira oportunidade. Esta é uma publicação sem fins lucrativos, e encontra-se livre de pagamentos de direito de autor no Brasil, protegida pela Lei № 9.610, Título III, Cap. IV, Art. 46, Inciso VIII. 


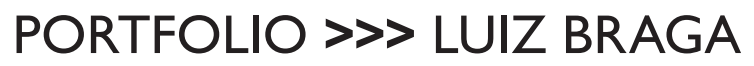

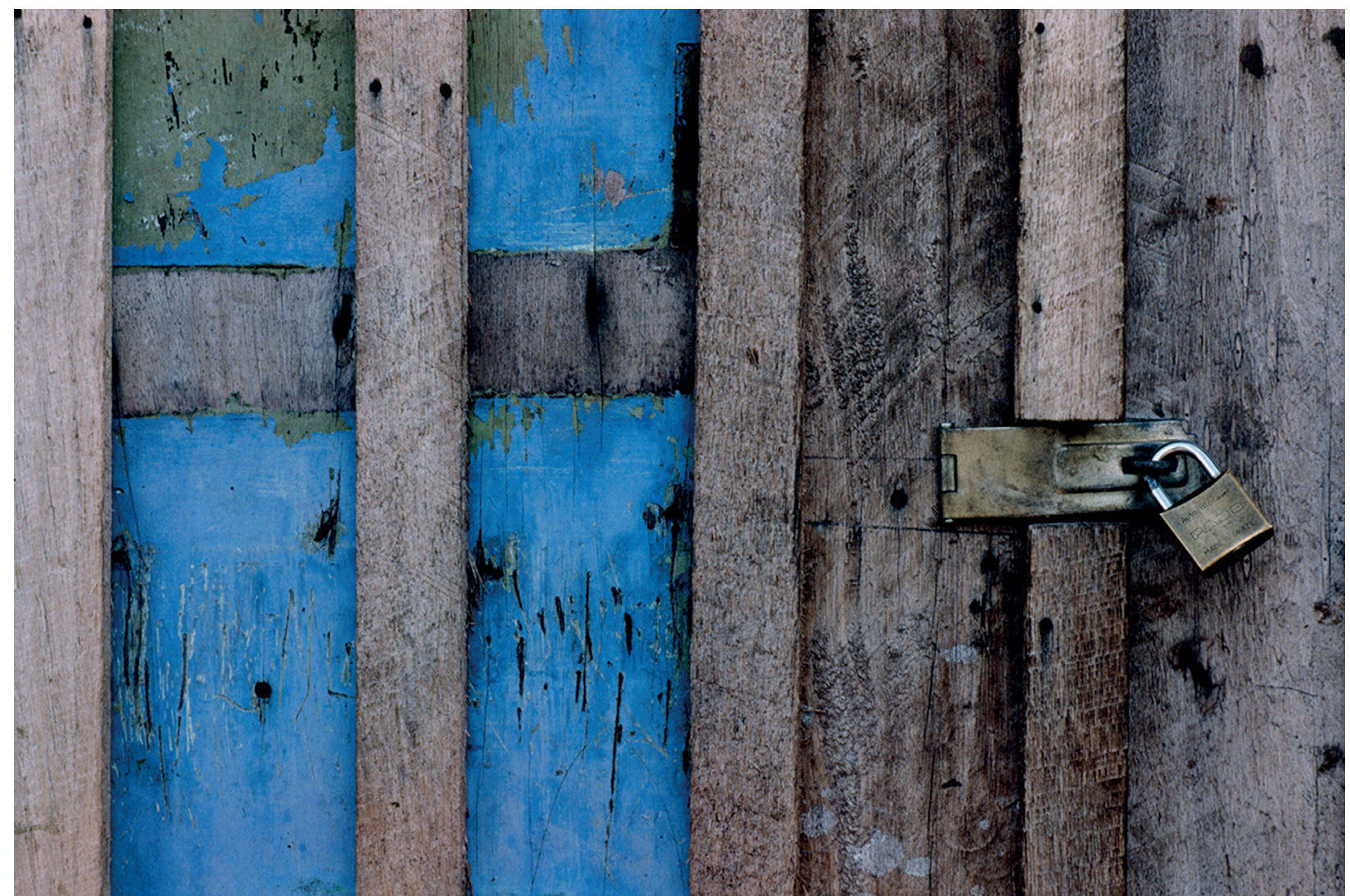




\section{NO ACENDER DA ÚLTIMA LÂMPADA, A ESTRANHA LUZ}

A produção de Luiz Braga faz parte de um imaginário amazônico, que há décadas vem observando com olhar cuidadoso, a registrar as pessoas que vivem na região e sua produção estética. Tive o prazer de assistir, ainda jovem, sua segunda exposição, Portfolio 80, em uma matiné na Signo's Clube. Retratos e cenas da cidade, que revelavam uma visão diferenciada e que me impactaram, somando-se às fotografias colecionadas nas páginas do tablóide Zeppelin. Ali o artista já estava presente. Desde aquele momento primal, passaria a seguira sua produção, que a cada momento sinalizava para um mergulho na vida das pessoas deste território tão multifacetado, atento à visualidade popular e aos modos de vida dos seus habitantes.

Em 1982, Braga desenvolve Visualidade Popular na Amazônia, associado ao Projeto Visualidade Brasileira do Instituto Nacional de Artes Plásticas (INAP), da Fundação Nacional de Arte (FUNARTE). Com este trabalho, Braga aprofunda o seu olhar sobre as manifestações da cultura popular, tão presentes no cotidiano do povo amazônida. Elementos em suas cores são captados em detalhes, traduzidos em construções precisas que revelam em objetos do dia a dia uma transcendência ao comum. Daí emerge No Olho da Rua (1984), sendo muito bem recebida por pesquisadores e críticos da fotografia, como Arlindo Machado e Stefania Bril.

Também é marcante seu projeto seguinte, que resultaria na mostra em preto e branco À Margem do Olhar (1987), que traz os personagens da cidade e do interior em retratos nos quais a dignidade e simplicidade evidenciavam a gente da Amazônia em seus pequenos gestos, em pormenores que romperam com estereótipos. Luz e texturas refinadas revelam sinais e vestígios. Há intimidade e um fascínio em olhar nos olhos do outro e pedir licença. Sem exotismos, há um respeito a este outro que vive à margem e que precisava, e ainda necessita, ser visto, enxergado. $E$, com este trabalho, Braga recebe um dos prêmios mais importantes da fotografia brasileira: o Marc Ferrez.

Crítico, em um desafio constante de questionar-se sobre processos e linguagens, sobre como a luz e a cor se manifestam na região, em que luminosidades distintas pintam cenas em mesclas cromáticas entre o natural e artificial, o artista fotografou o universo ribeirinho na luminosidade do limiar do dia, na agudeza do tempo que se esvai e das luzes que se acendem. Luz de mercúrio, lâmpada fluorescente misturaram-se com o calor do final do dia, explorando a cor e sua temperatura ao seu limite, capturadas em um período de tempo exíguo, desenvolvendo uma pesquisa imensa, na qual grande parte de seus personagens surgem em situações que transcendem a imagem. A ideia de "certo" ou de "errado" fotográfico é contrafeita em sua fotografia. Braga subverte a técnica.

Deste momento da experimentação em que recebe o prêmio Leopold Godowsky Color Phothography Award, da Universidade de Boston, EUA (1991), nasce a exposição Anos-Luz, ao revelar seu sofisticado olhar. De lá para cá, em uma trajetória que coleciona premiações, como a Bolsa Vitae de Fotografia (1996) e a participação na 53ª Bienal de Veneza (2009), Braga vem consolidando uma obra densa, na qual a técnica é insurgida continuamente no exercício da linguagem. Assim foi com suas Night Visions, em que a subversão de um recurso técnico particular o propicia um novo mergulho no universo regional por meio da captação da luminosidade infravermelha. 
Algumas dessas experiências reunimos aqui nesta edição, que convida o leitor a adentrar ao território do artista, como quem adentra em seu arraial da luz, com o vigor, com a dedicação que suas imagens nos conclamam. Tecemos um caminho, apresentamos personagens, lugares, particularidades de uma Amazônia possível, que os olhos de Braga traduzem no encontro com homens e mulheres que constroem saberes nesses locais de sua tão vivida periferia ribeirinha, onde traça seu mapa do éden, em uma grande homenagem à retumbante natureza humanizada. Aqui, sujeitos e atmosferas que compõem o seu território, mesclam-se.

O olhar nos convida a atravessar estas ambiências-imagens, receber os olhares de volta dessa gente que está aqui, e que constitui a cada minuto suas experiências de vida. Juntamos tempos distintos para adentrar nesse universo, em uma Amazônia que está viva em cada feira, beira de rio ou rua das diversas cidades da região, e encontrar na obra de Braga um grande tributo ao humano e ao próprio luminoso presente no fulgurante piscar da última lâmpada.

Orlando Maneschy 


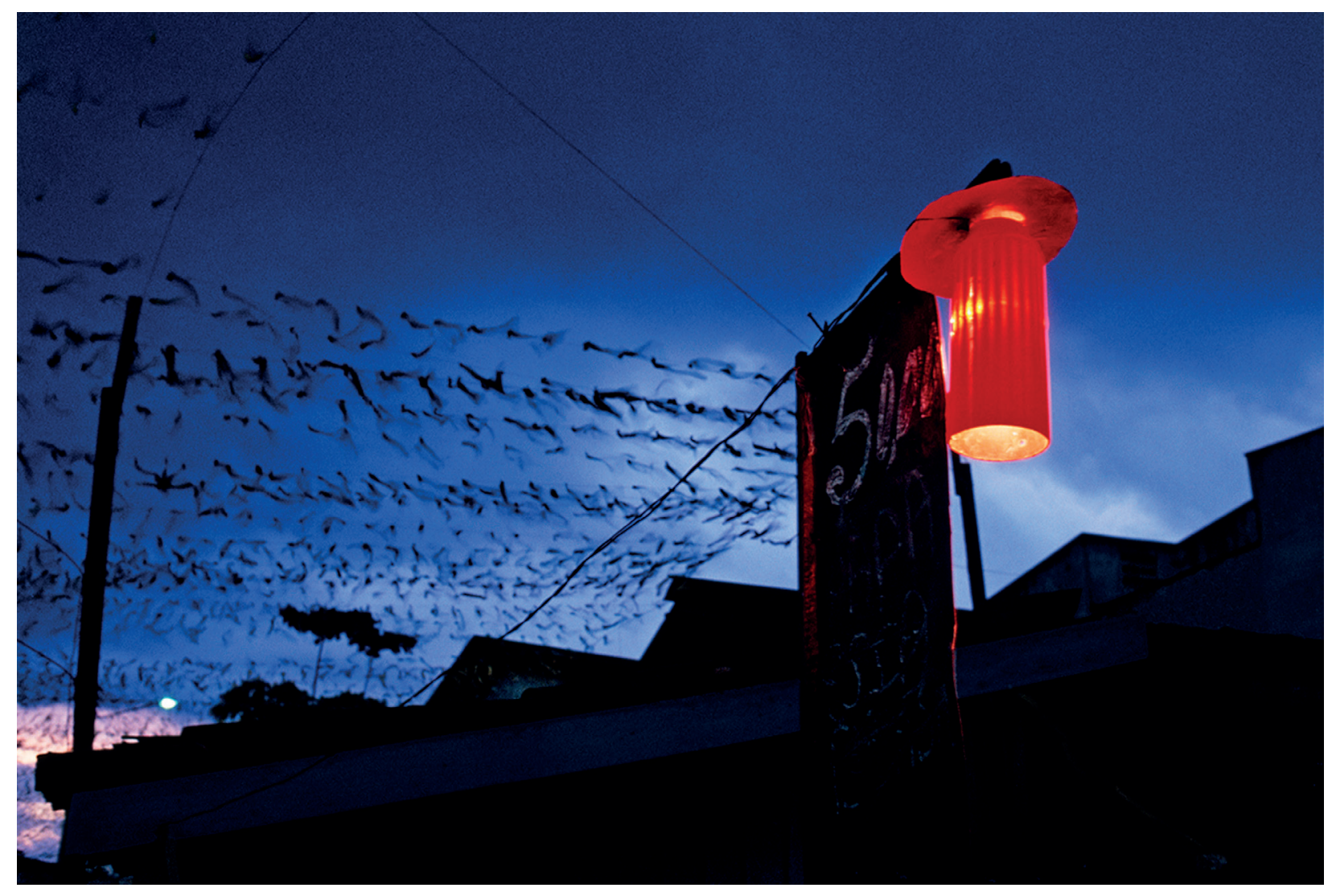

Lâmpada açaí,

1990

16 Arteriais | revista do ppgartes | ica | ufpa | n. 09 Dez 2019 


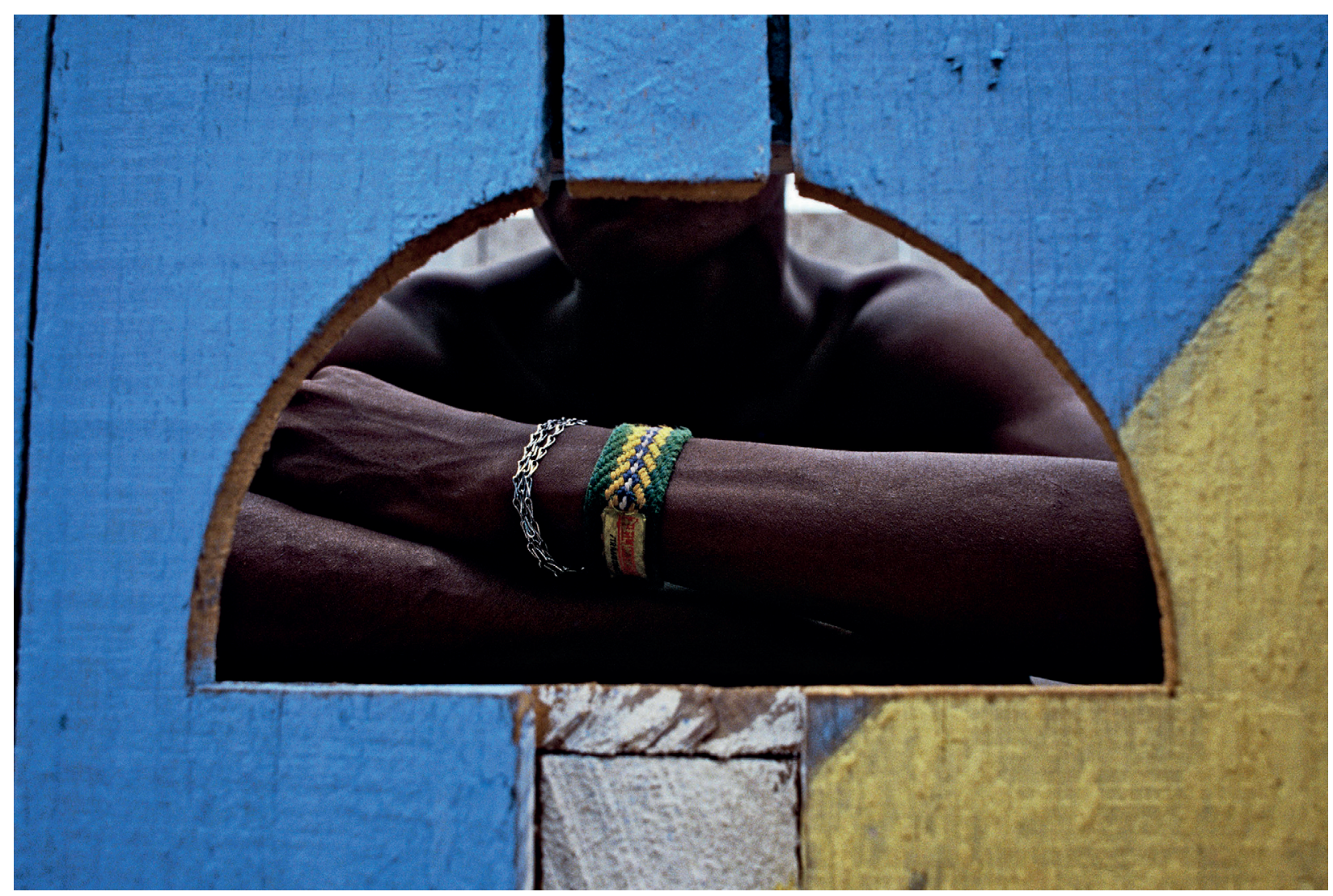

Bilheteria,

1987

Portfolio 


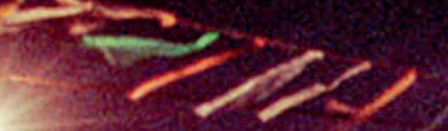

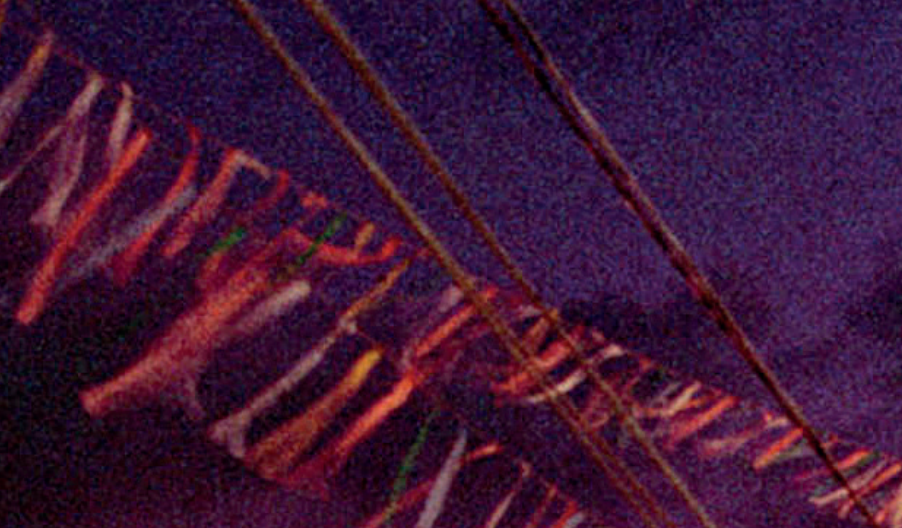

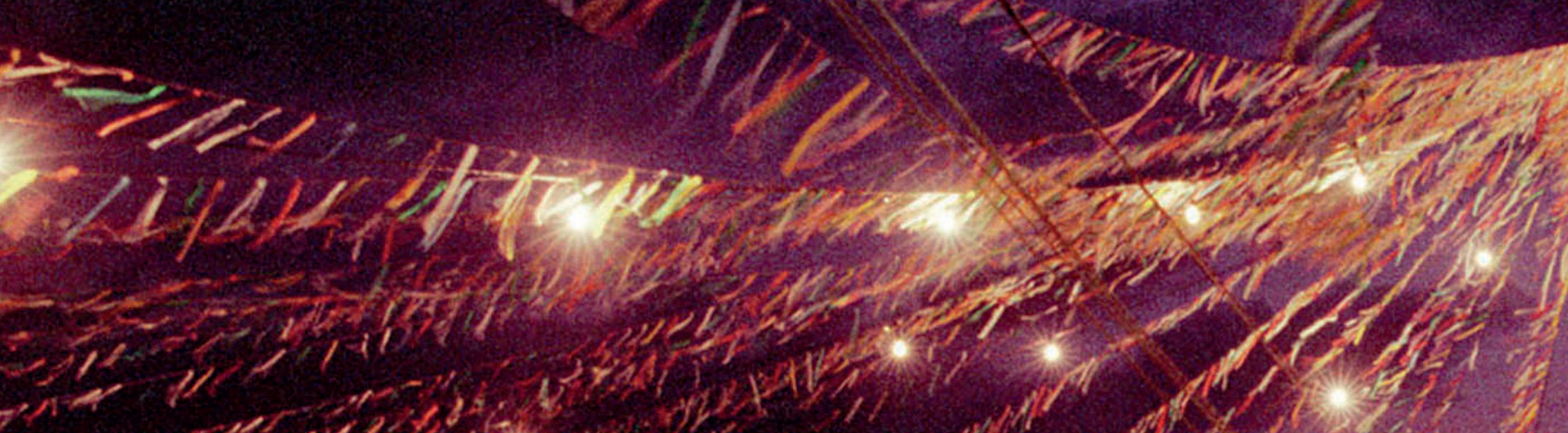

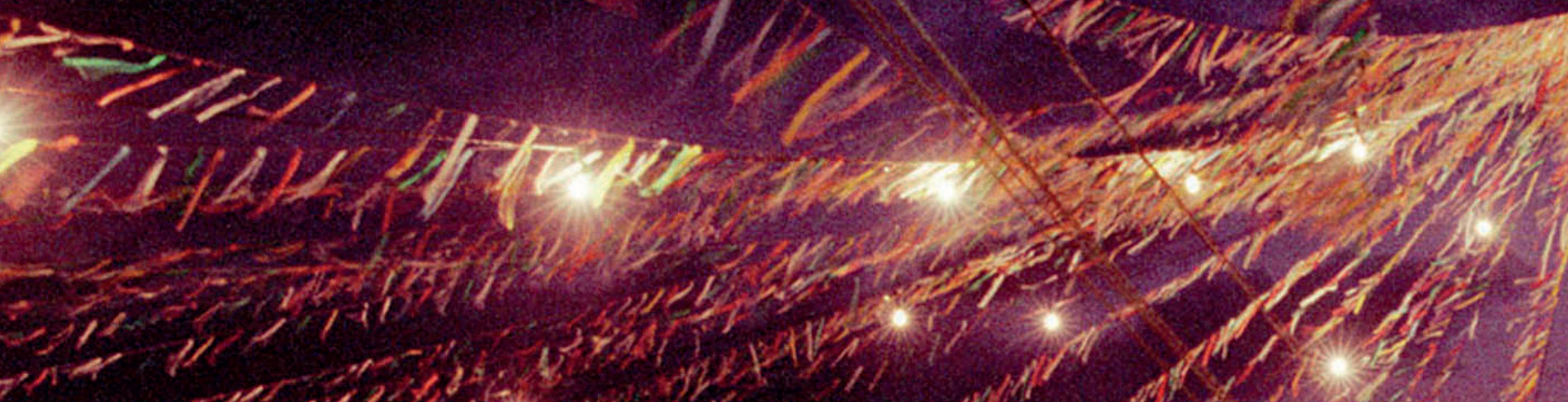

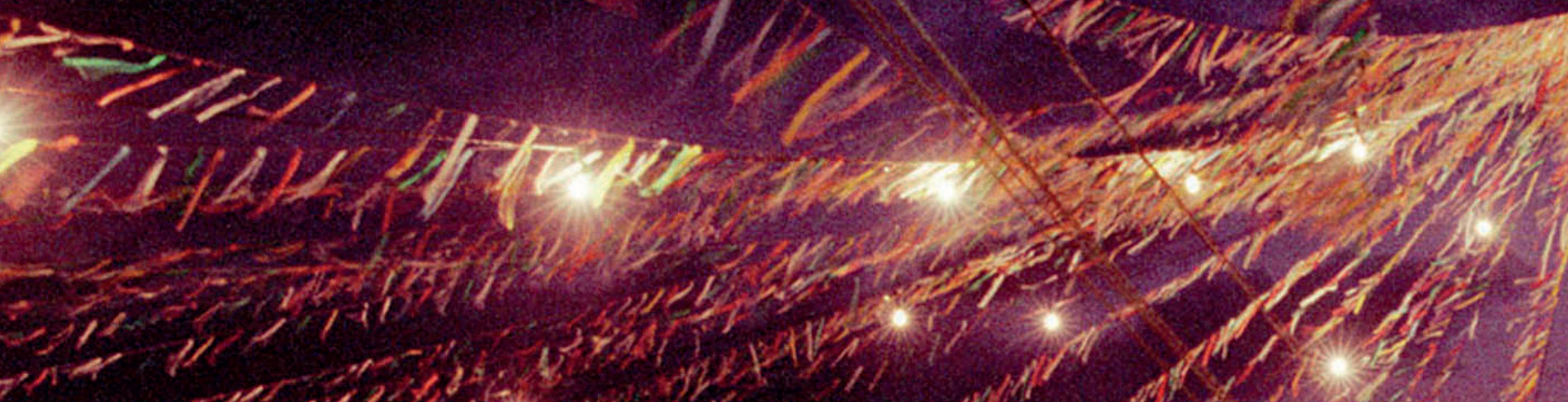

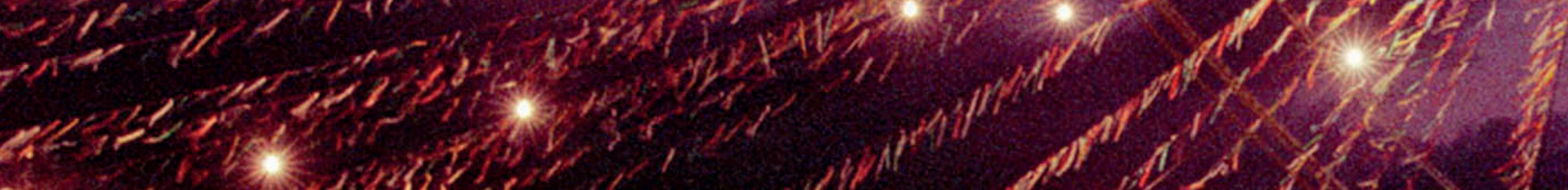
3. तis $3 \times 0 \%$

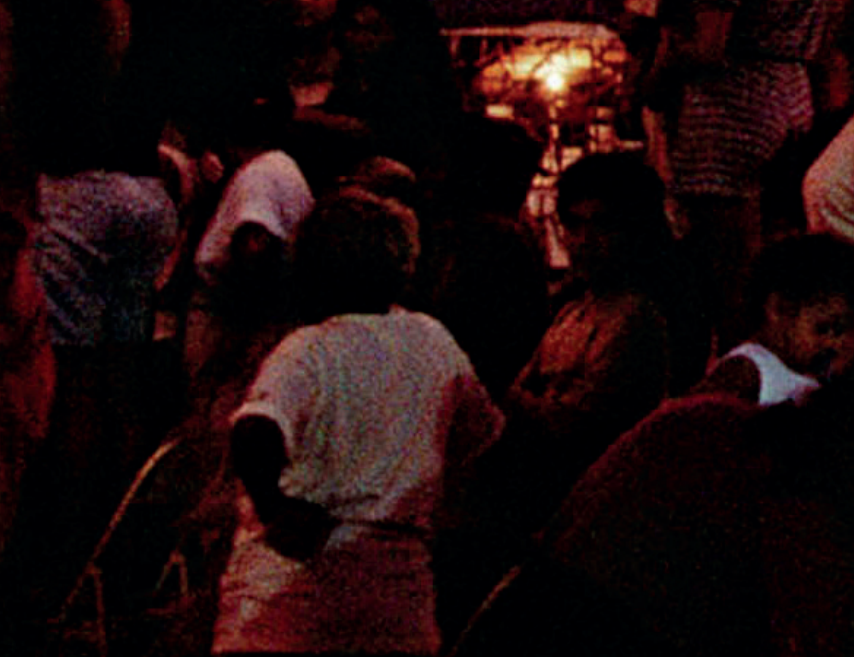
(19),

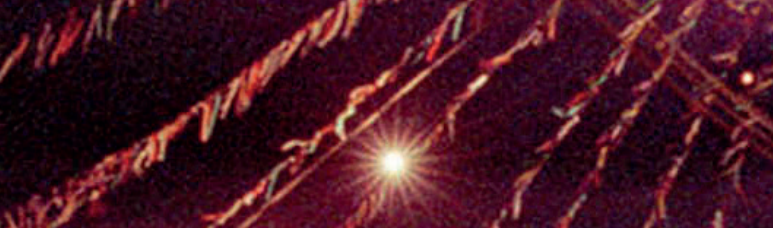


(3)

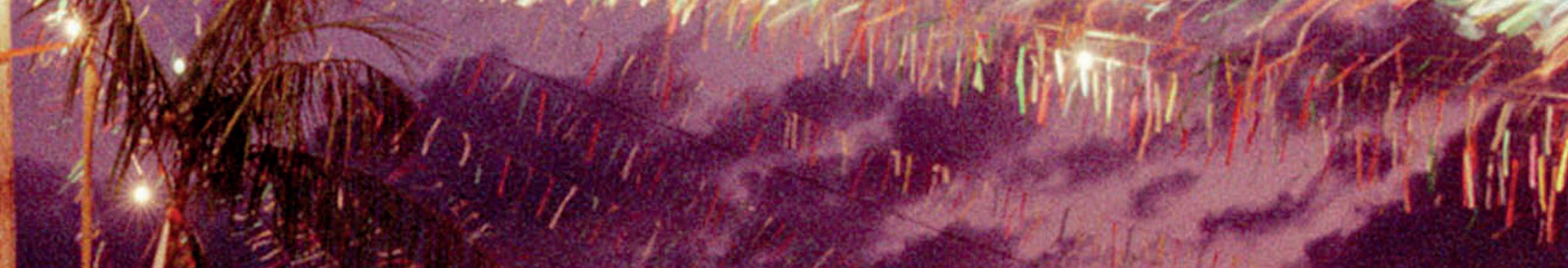
1.

4.
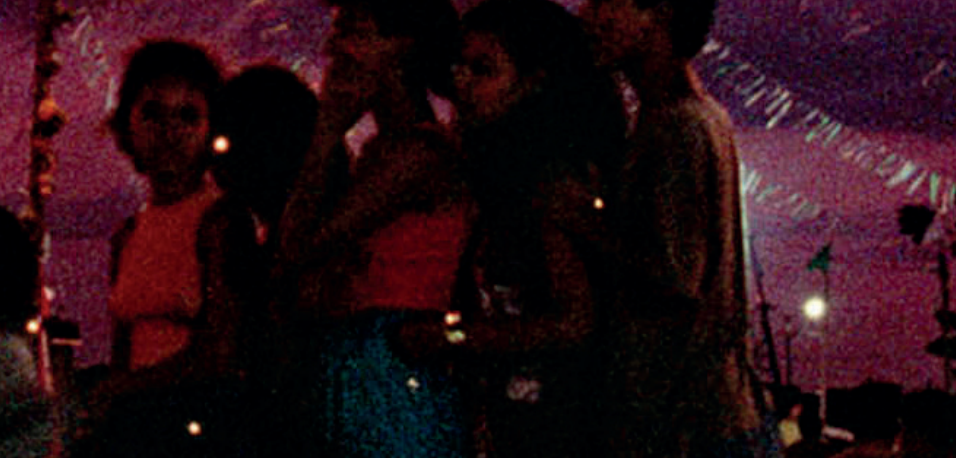

24. ning

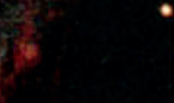

1)

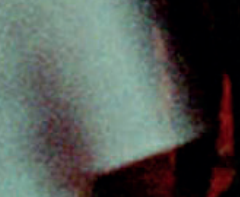

28

$3^{2}$ 


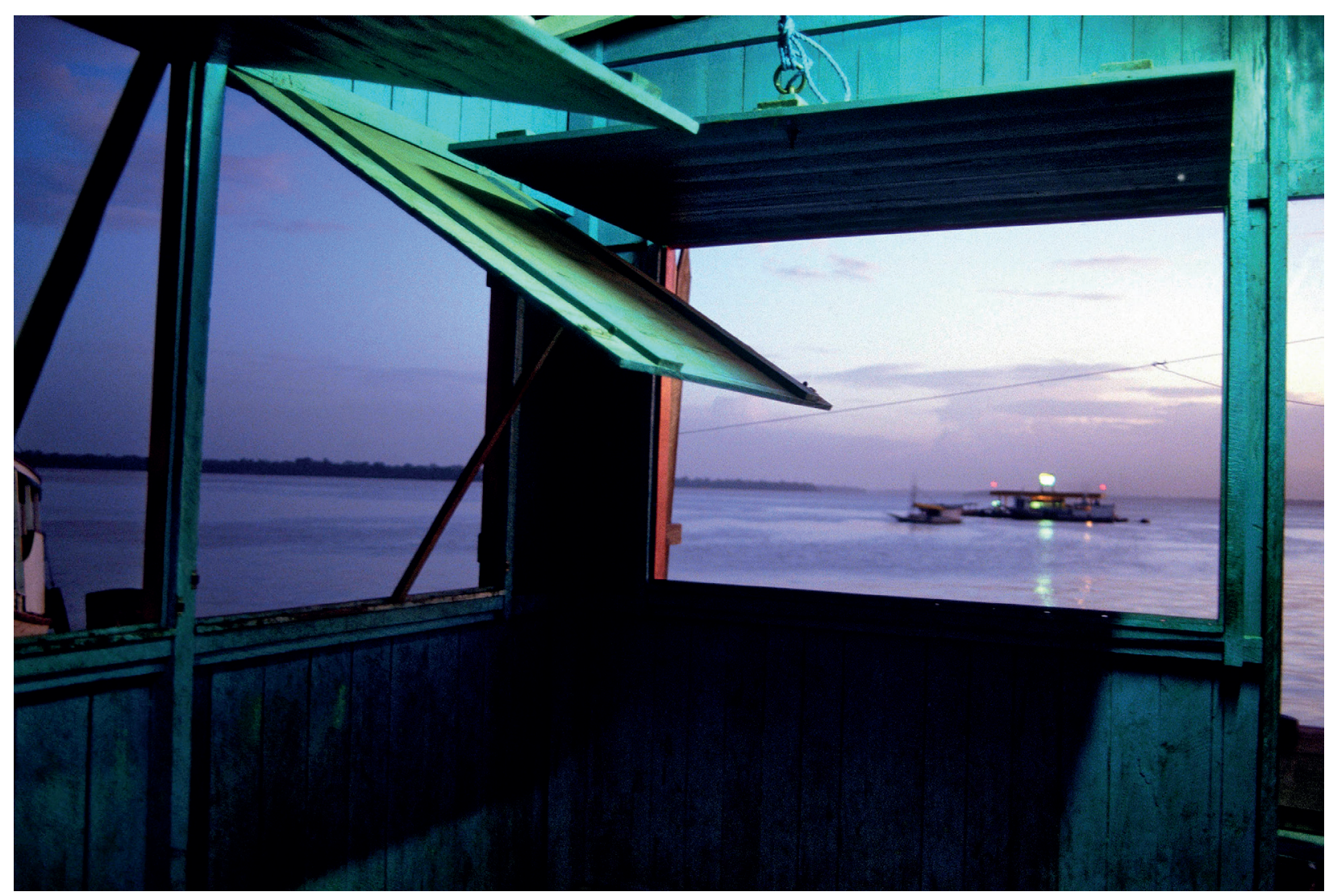

Janela do Rio Guamá,

1988

20 Arteriais | revista do ppgartes | ica | ufpa | n. 09 Dez 2019 


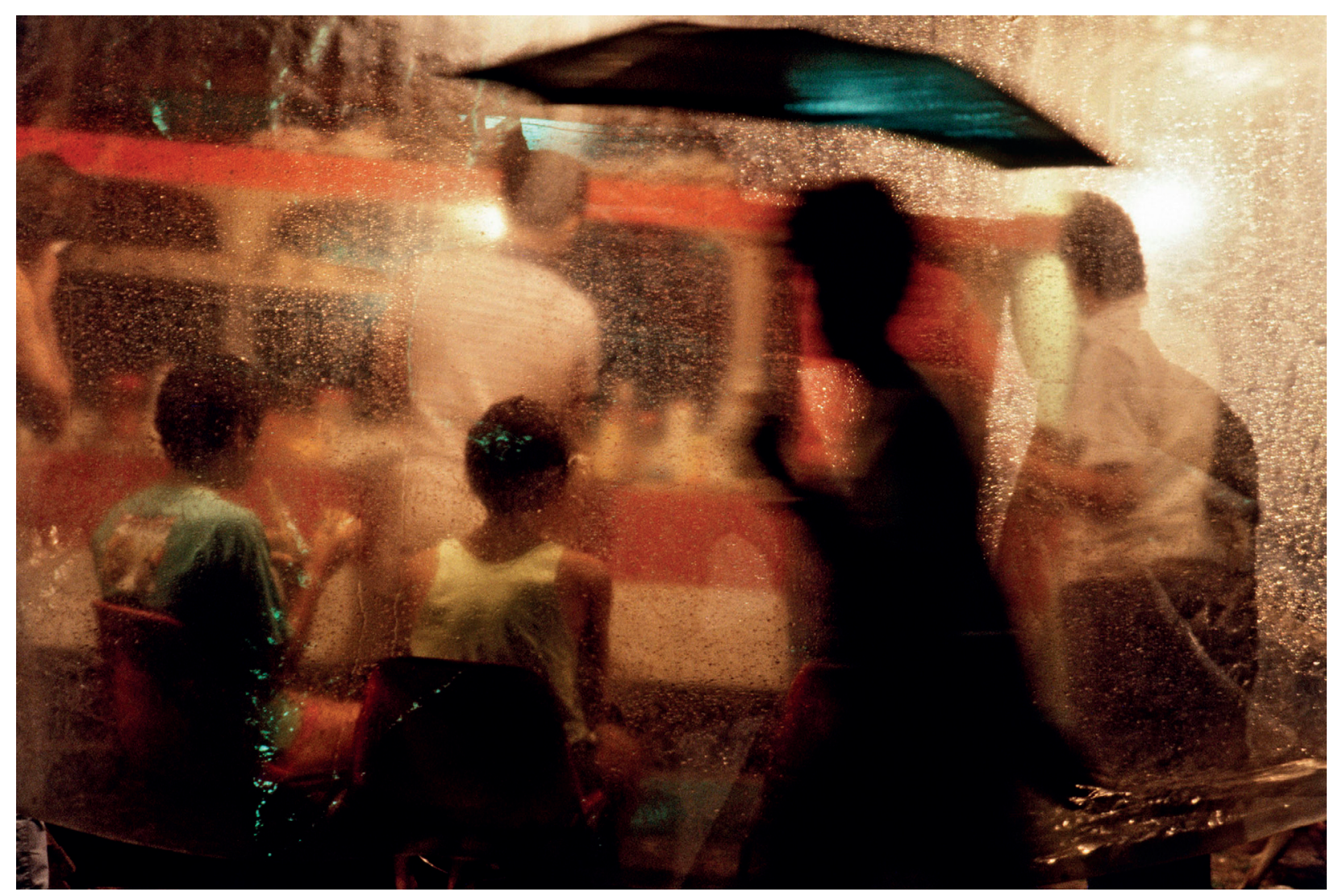




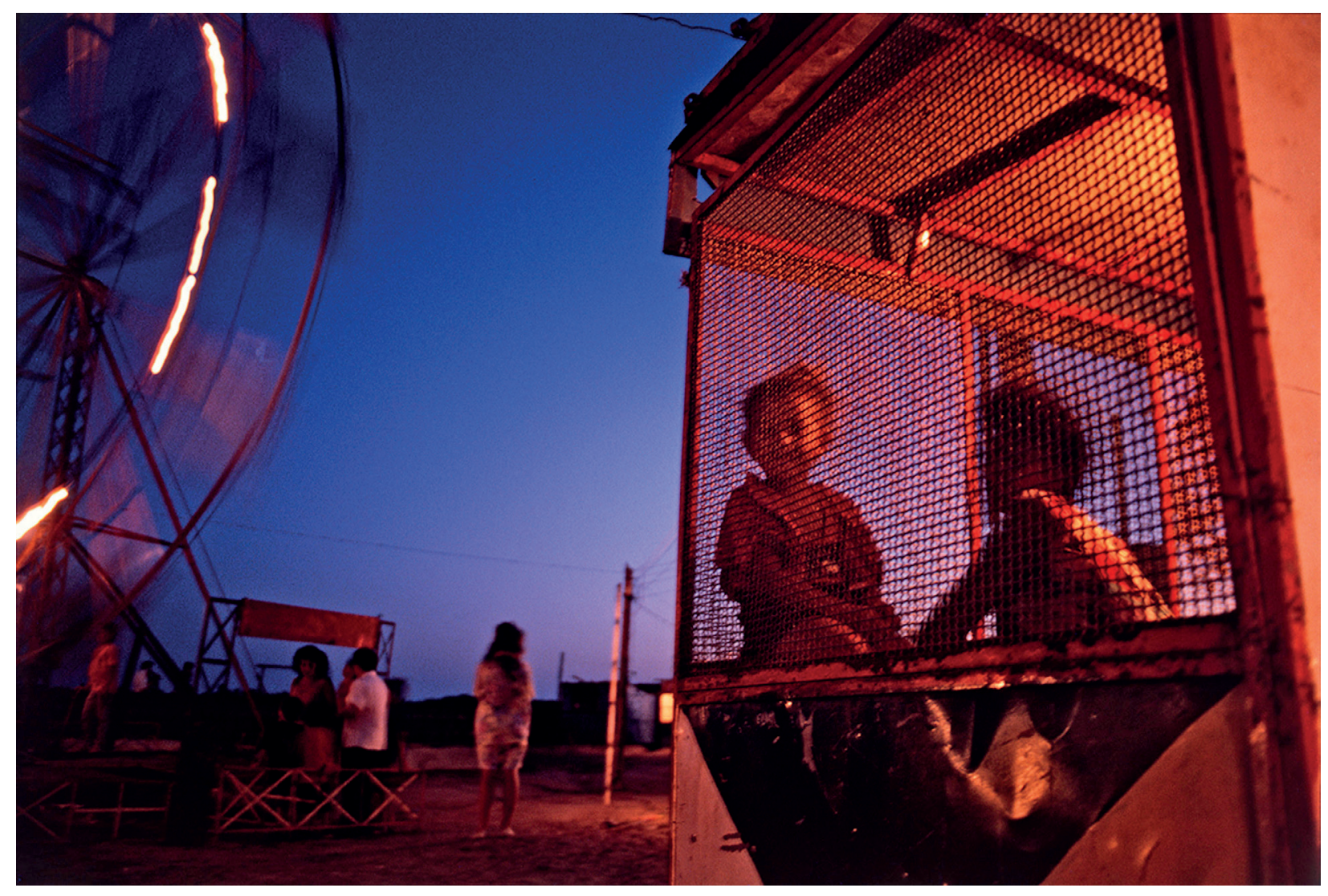

Parque,

1990

22 Arteriais | revista do ppgartes | ica| ufpa | n. 09 Dez 2019 


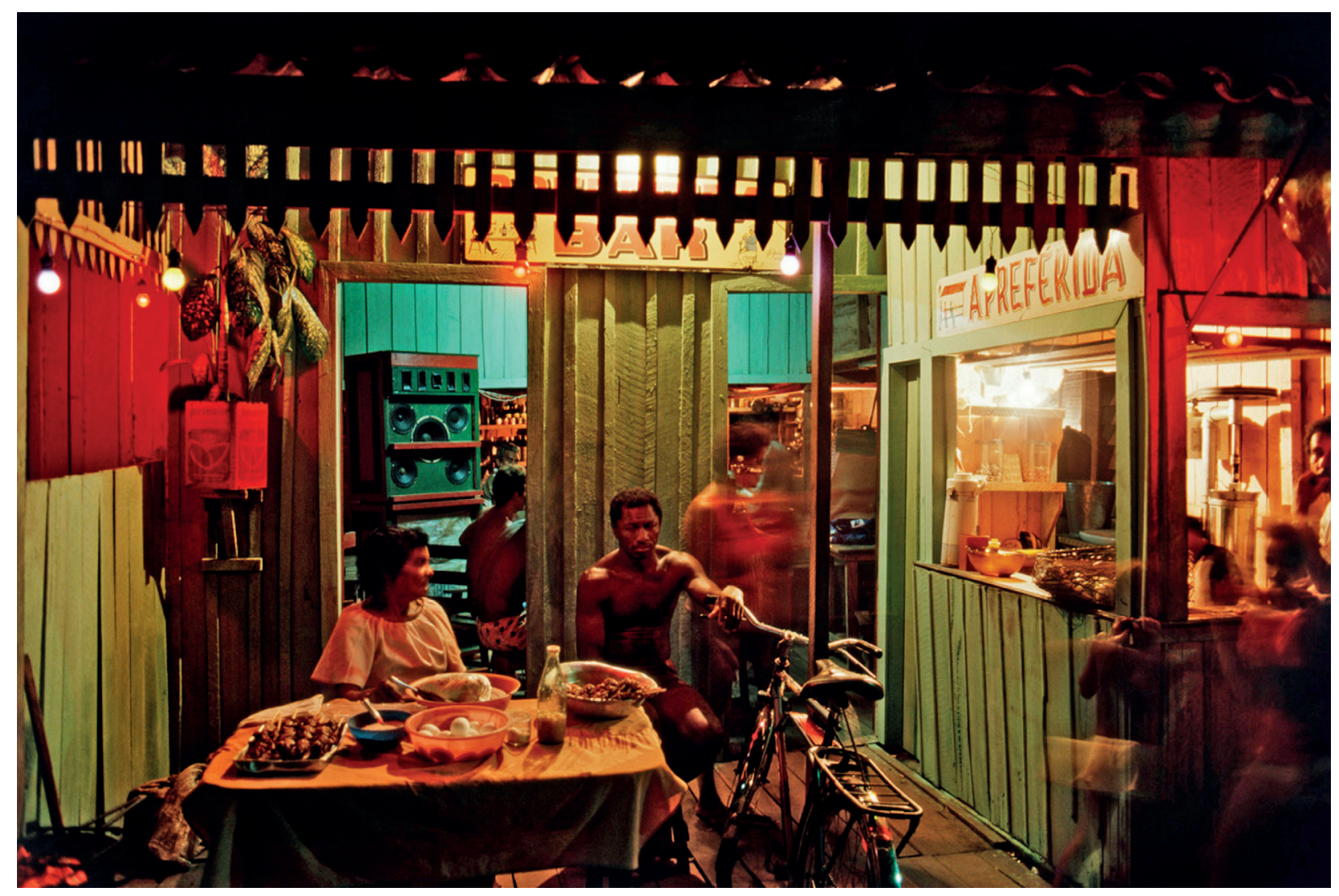




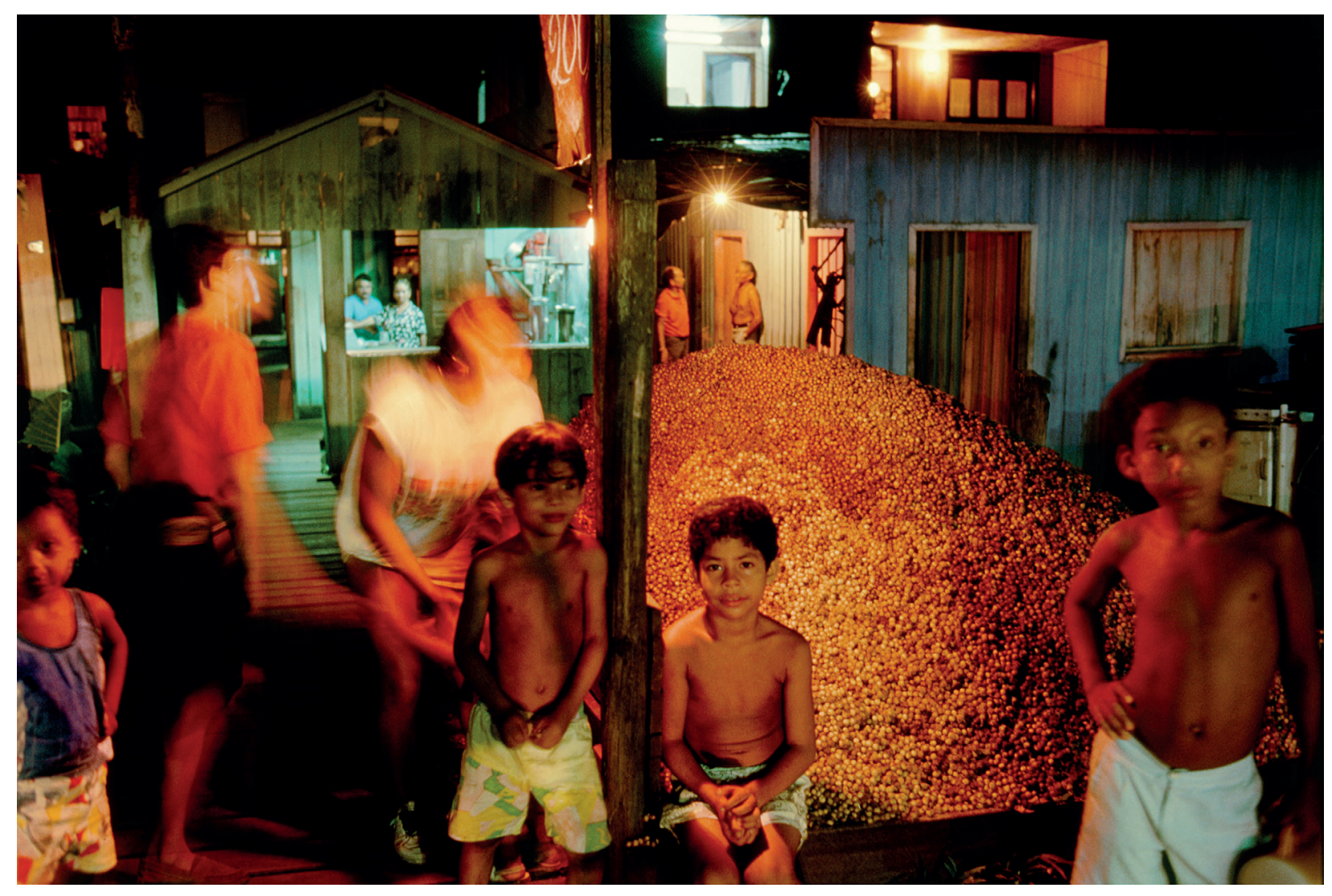

Meninos na venda de açaí, 1988 


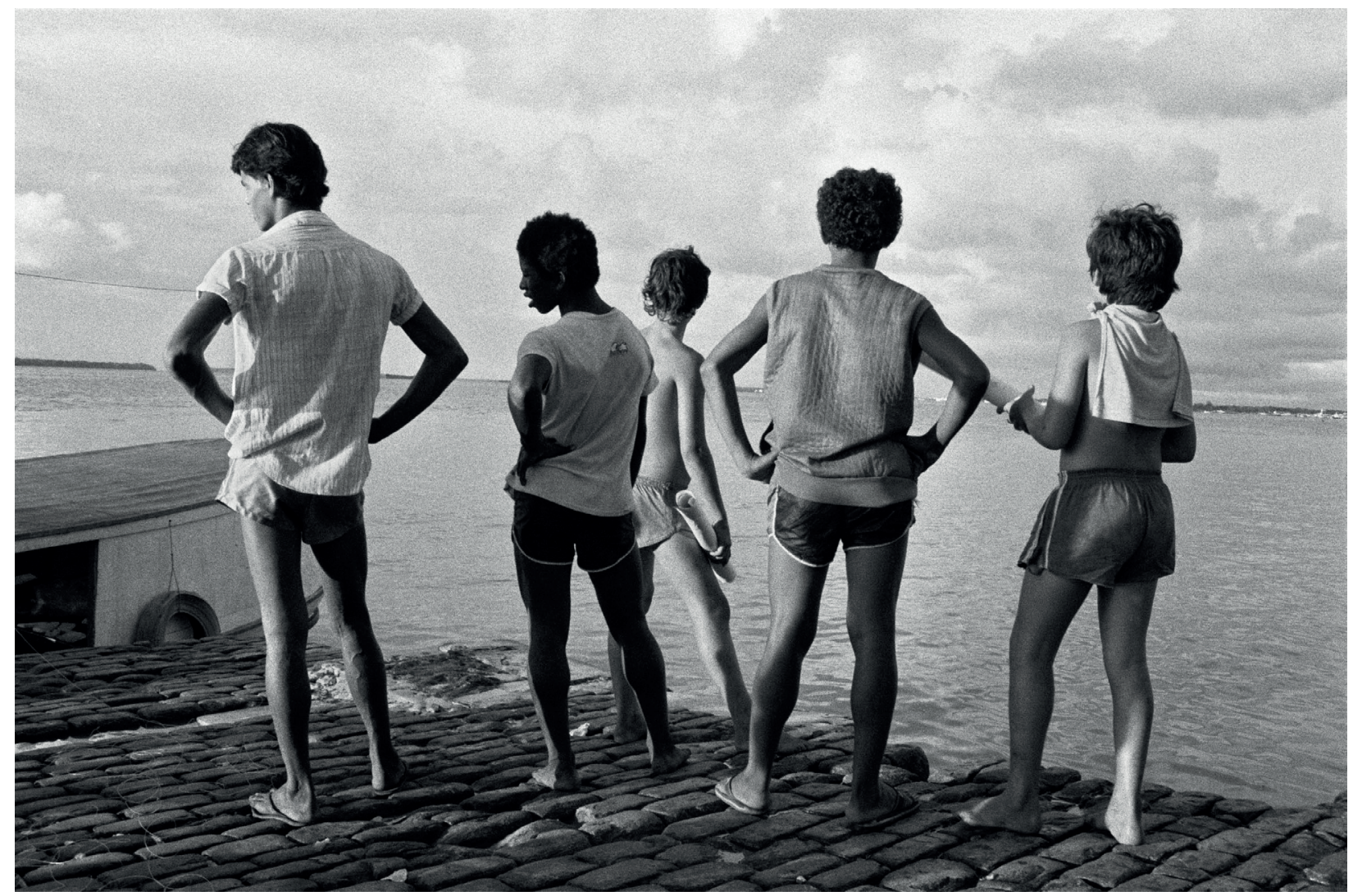

Meninos na beira, 


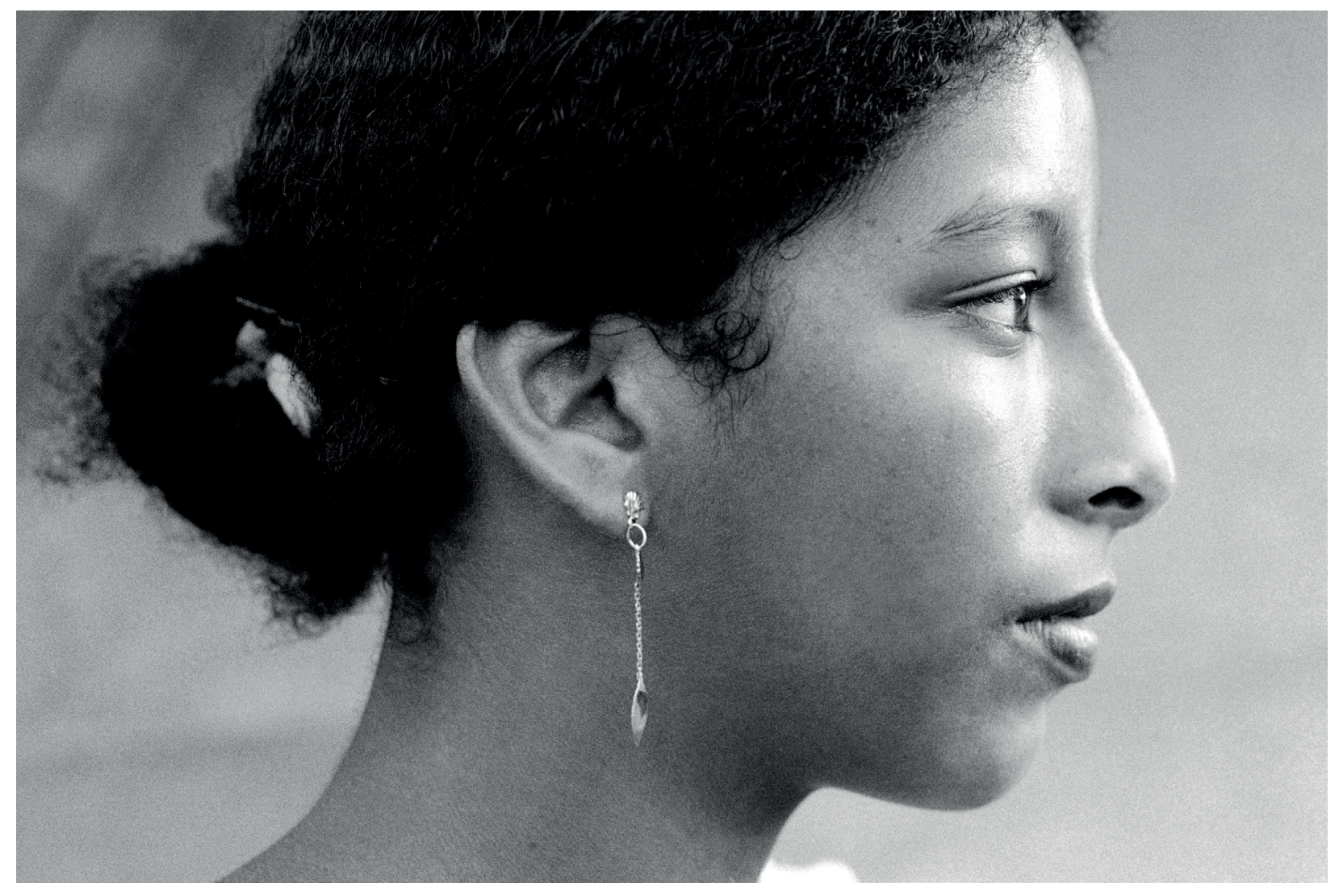

Rosa do Rio Paúba,

1986

26 Arteriais | revista do ppgartes | ica | ufpa | n. 09 Dez 2019 


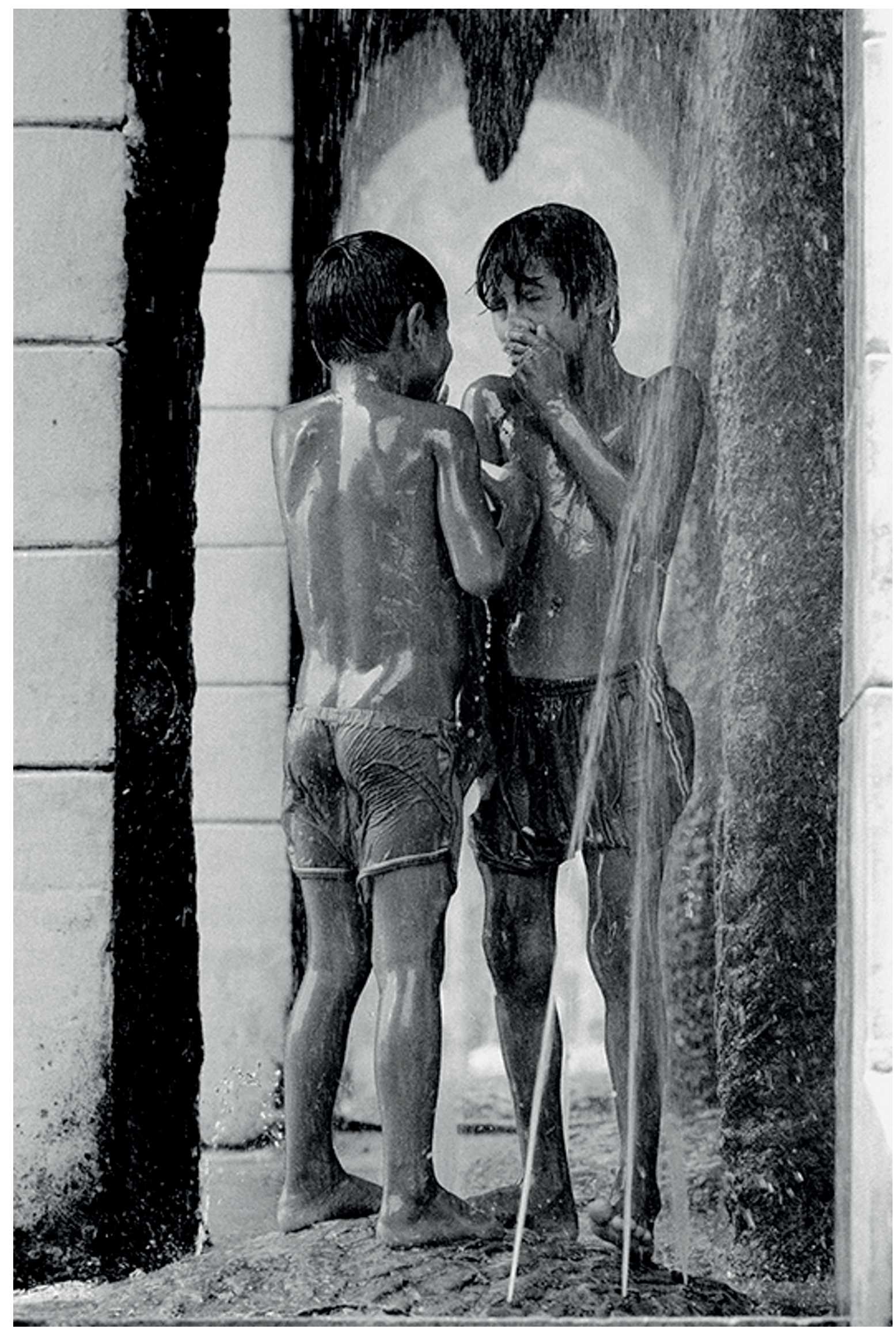

Meninos no chafariz,

1986 


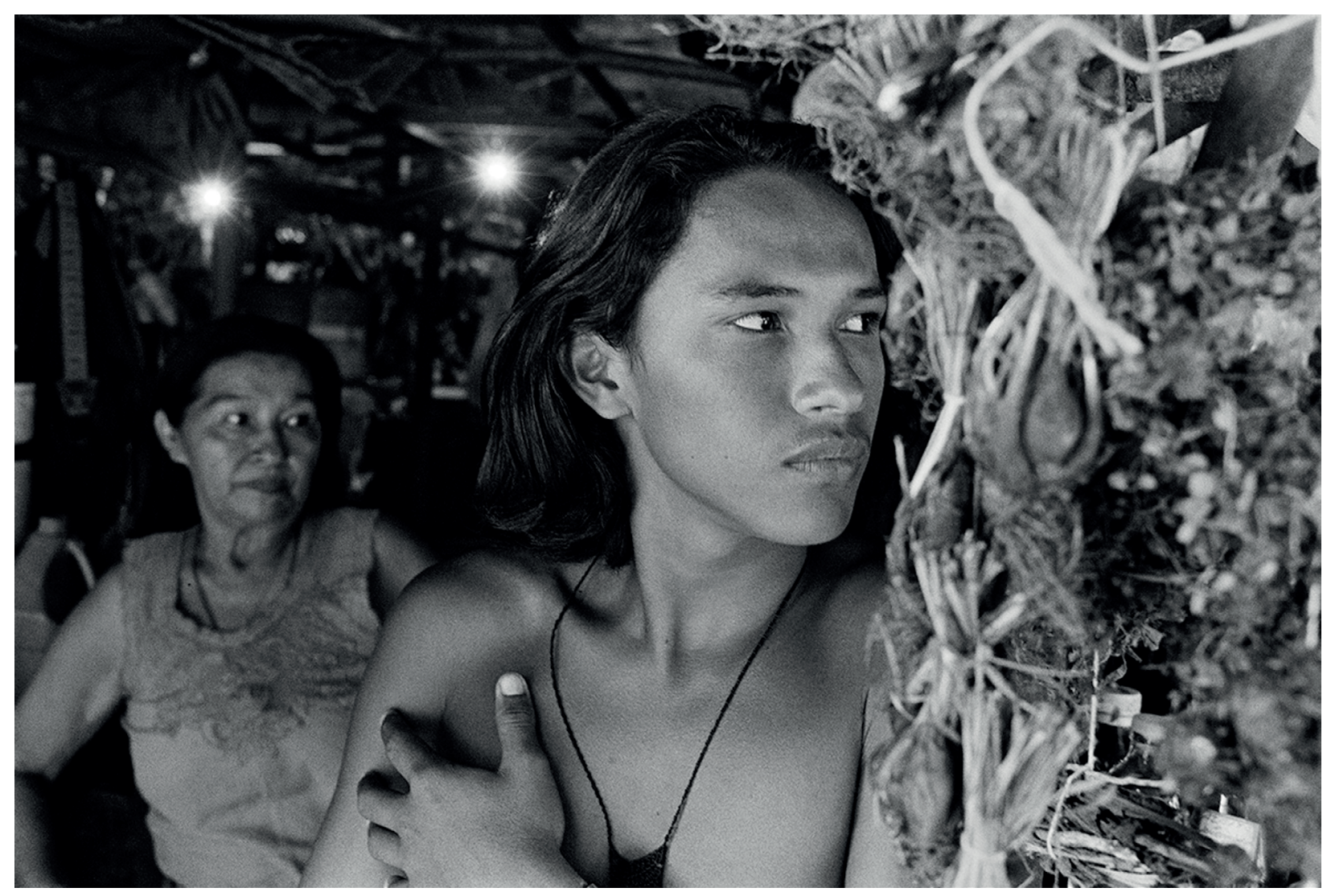

Miguel e Flora,

1999 


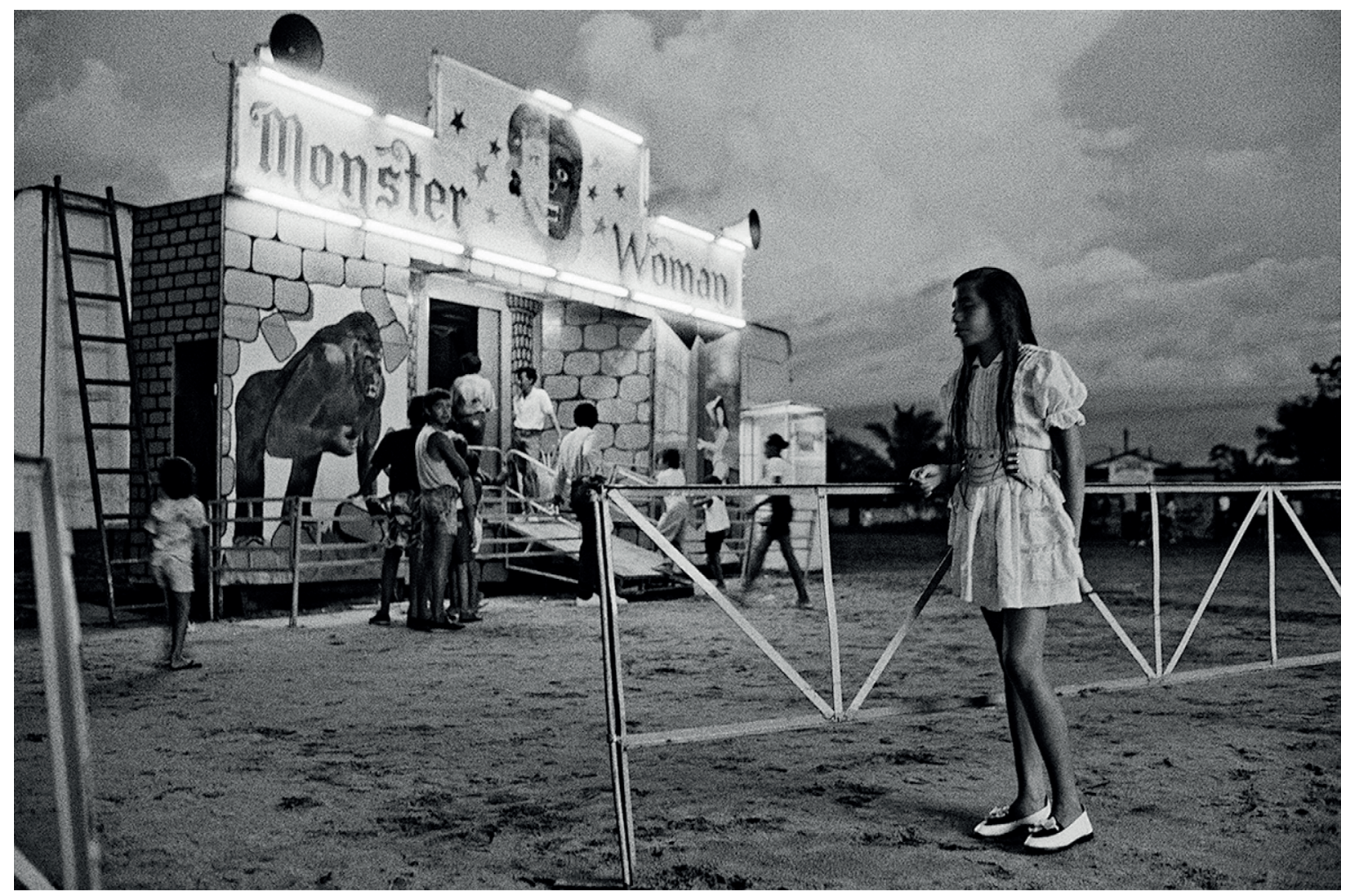

Monster Woman II,

1989 

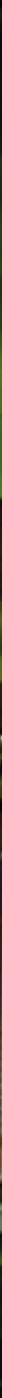

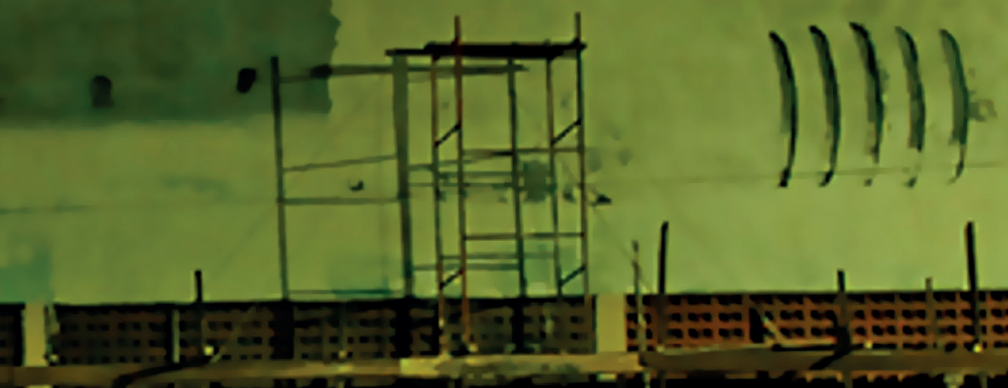

(9)

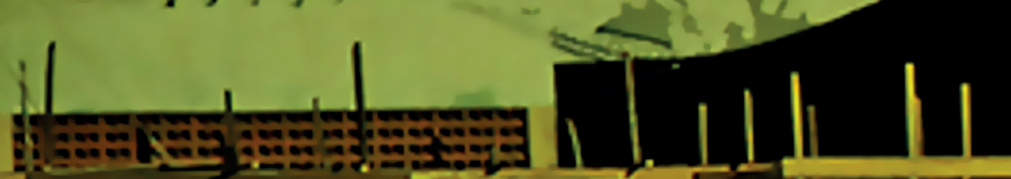

I0_t

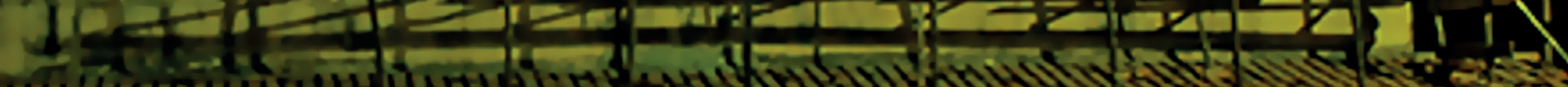
1/7)
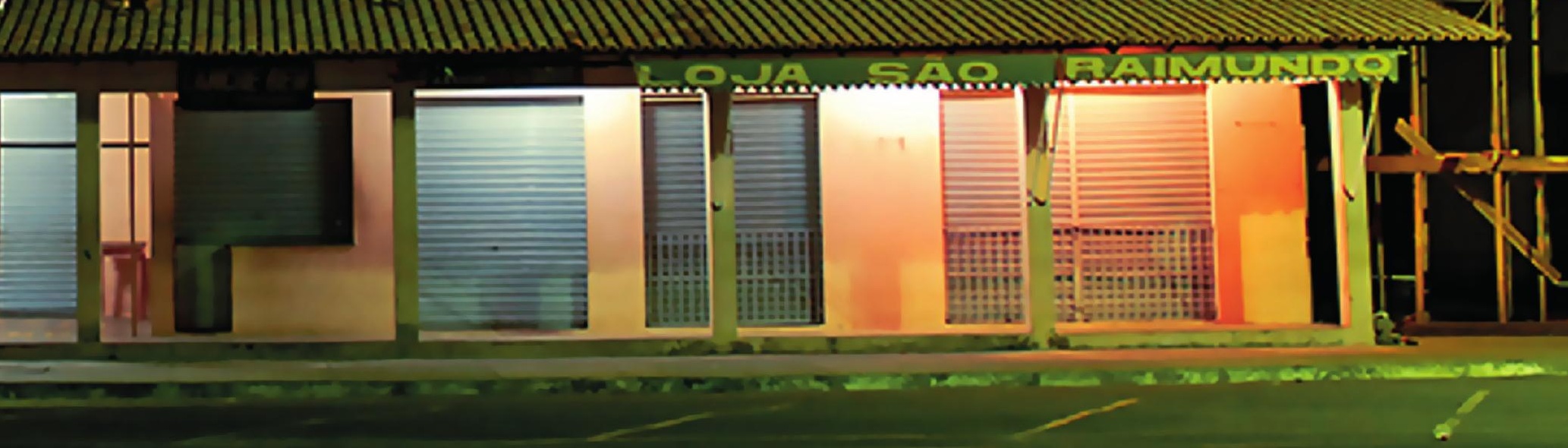


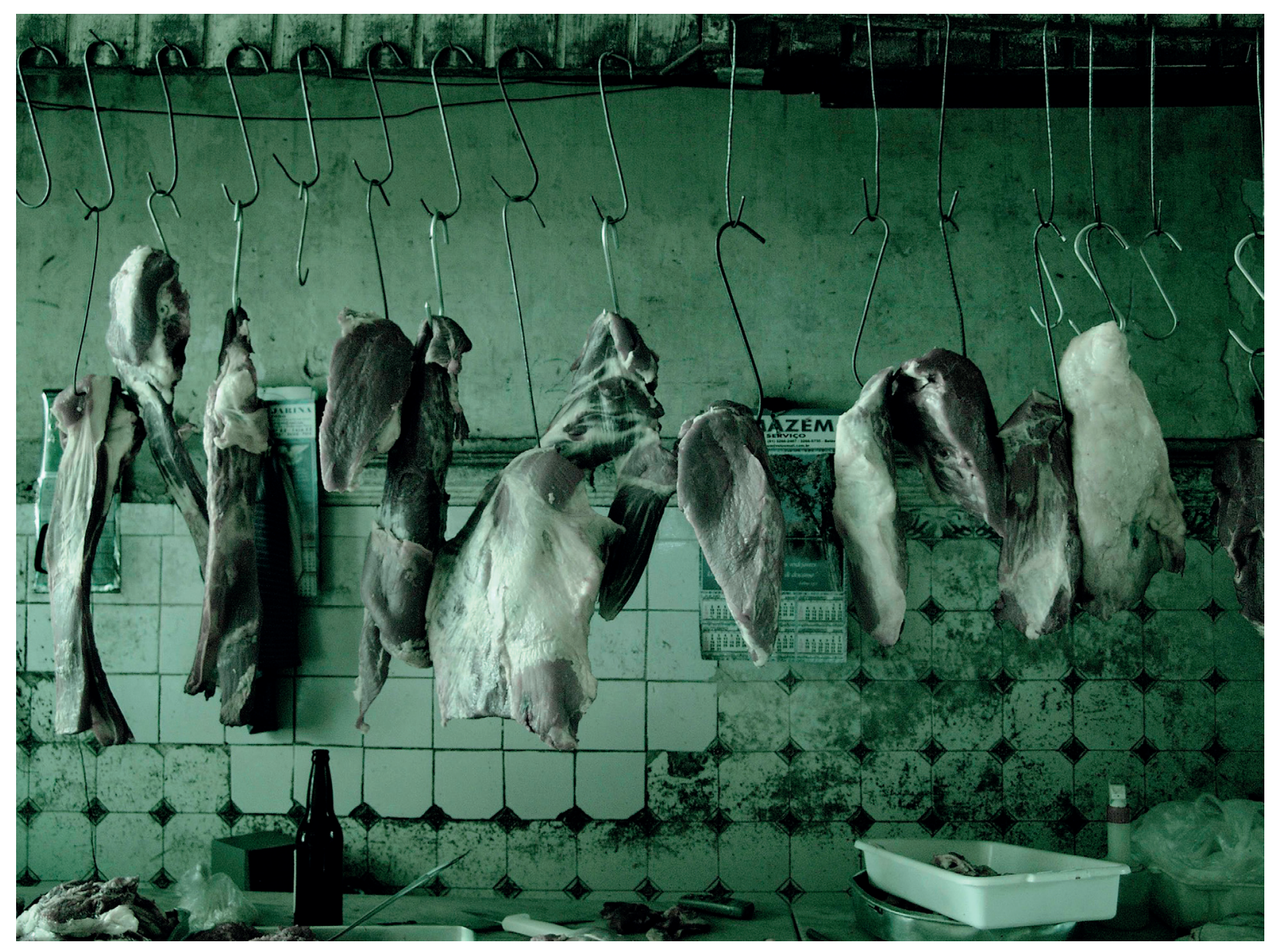

Mercado de carne,

2006 


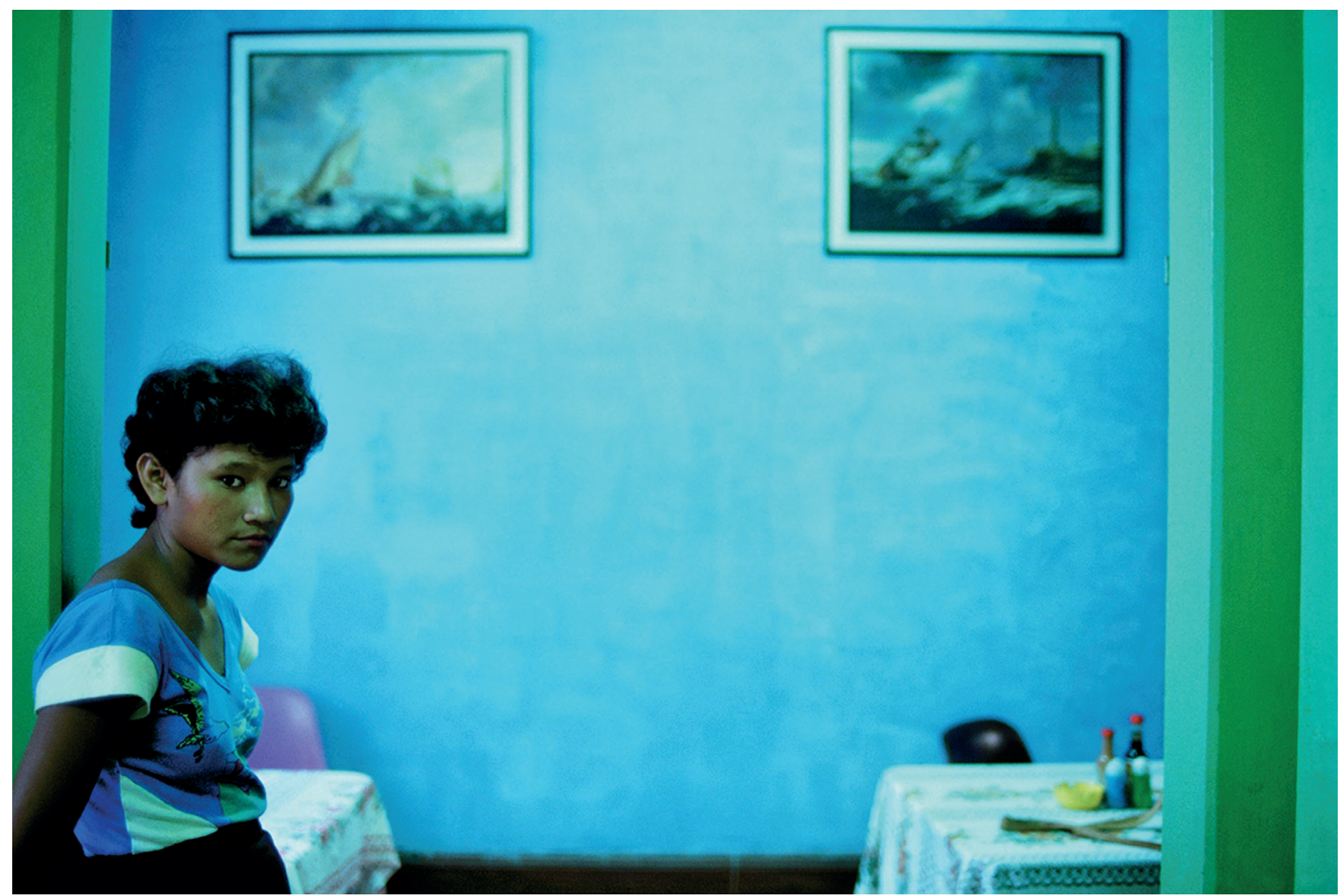

Garçonete no Ver-o-Peso, 


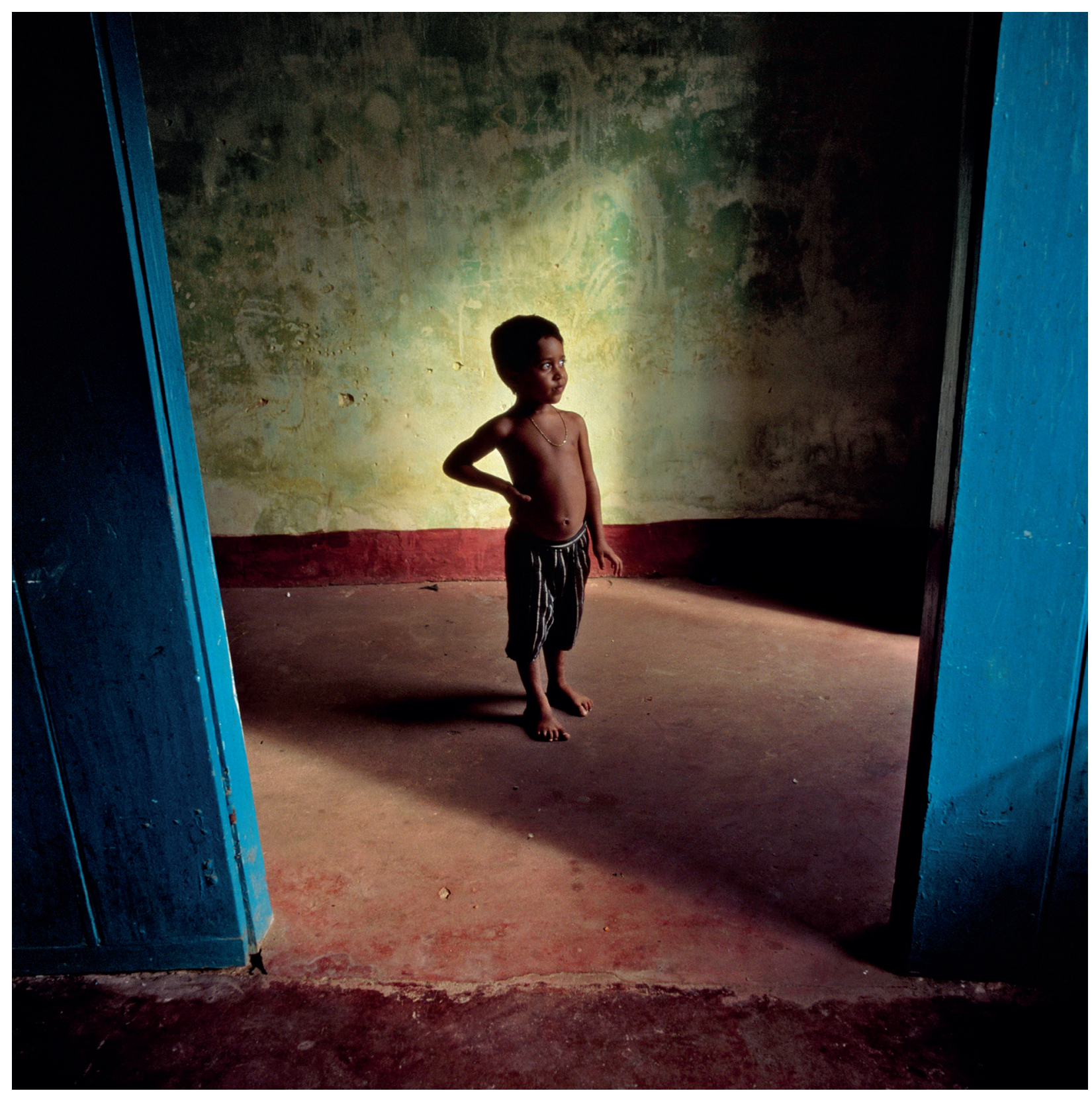

Casa de Nagô,

1988 


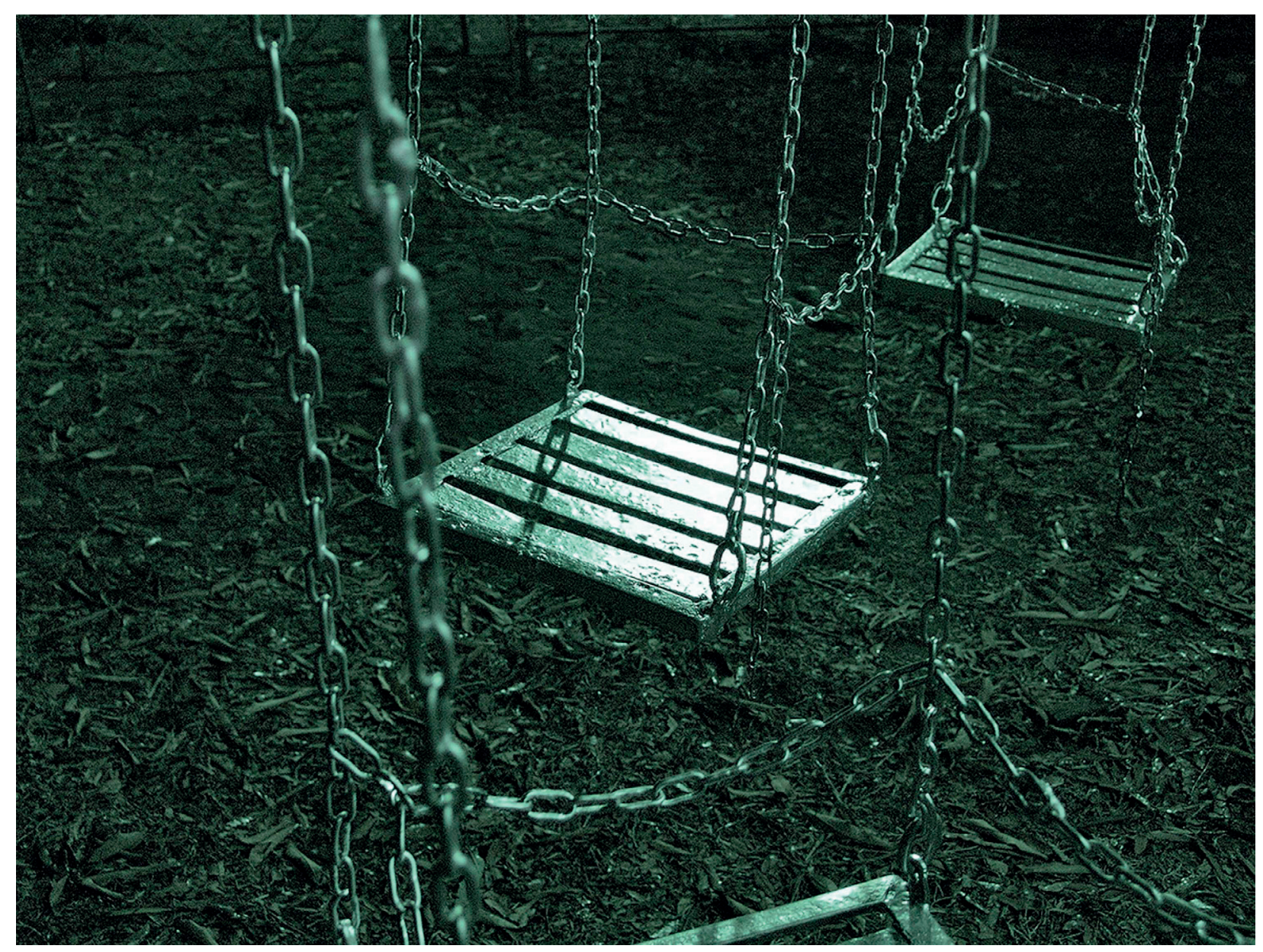

Balanços,

2004

Portfolio 


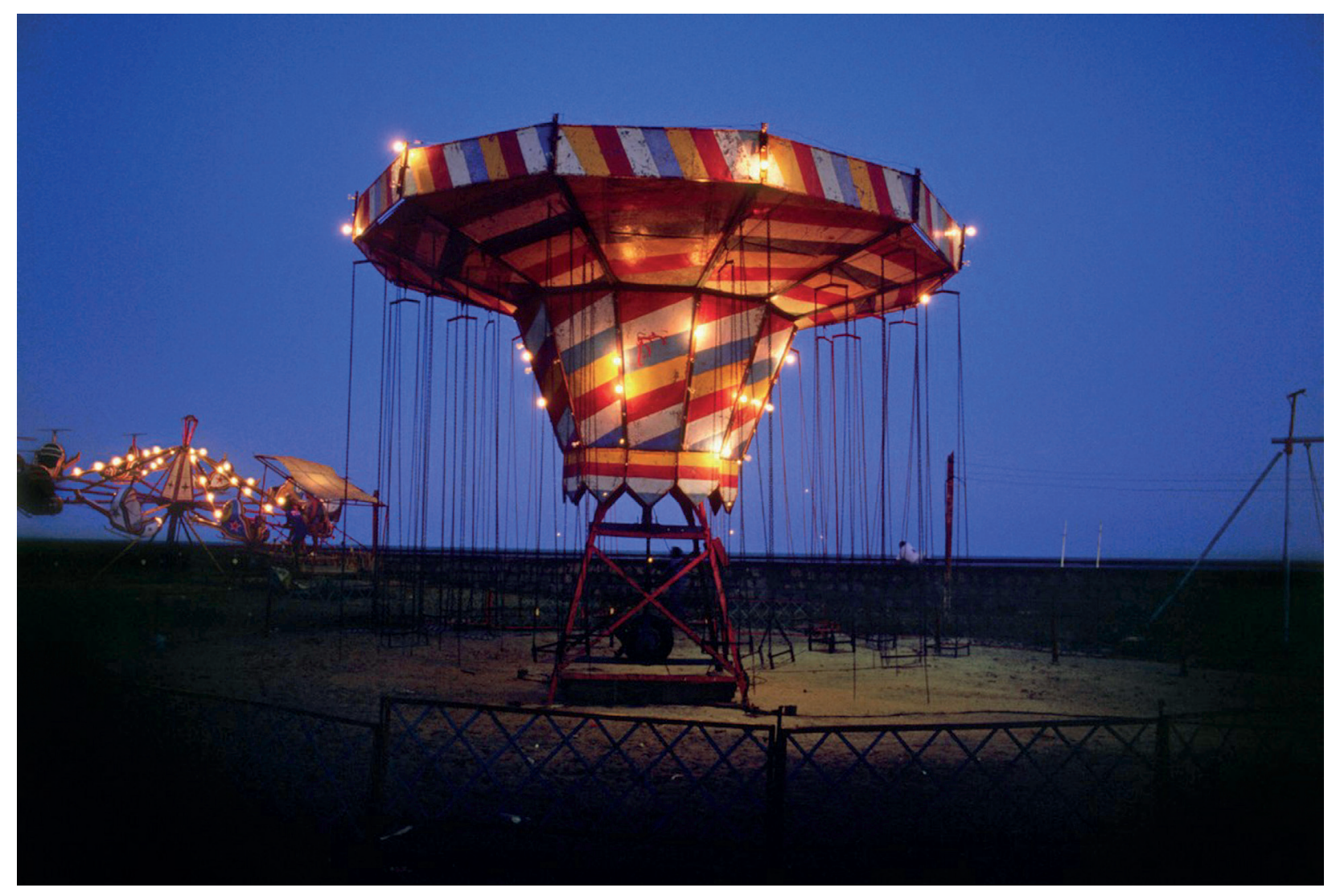

Roda mexicana,

1990 


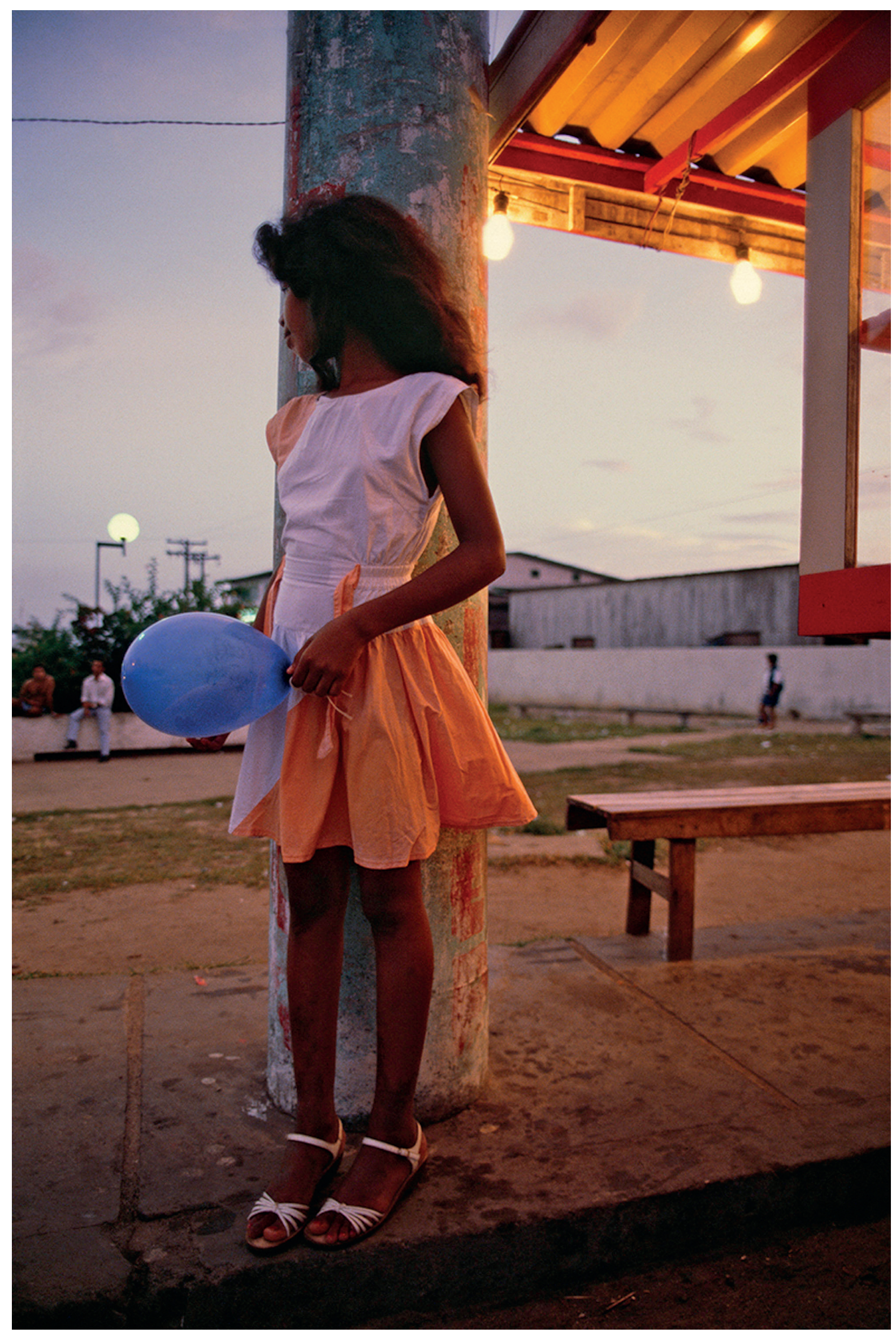

Menina e balão azul,

1990 


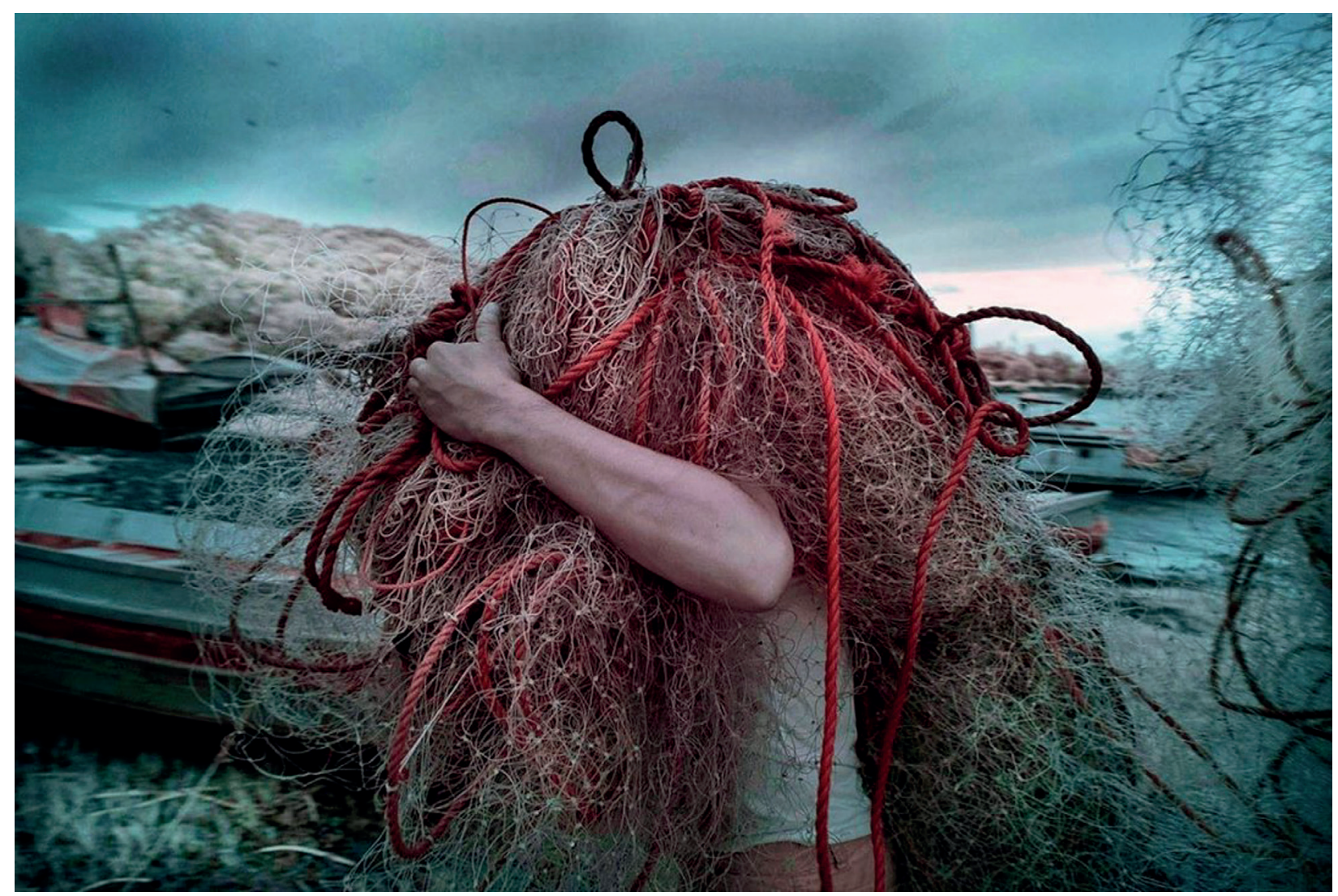

Em busca de Dagon,

2019 


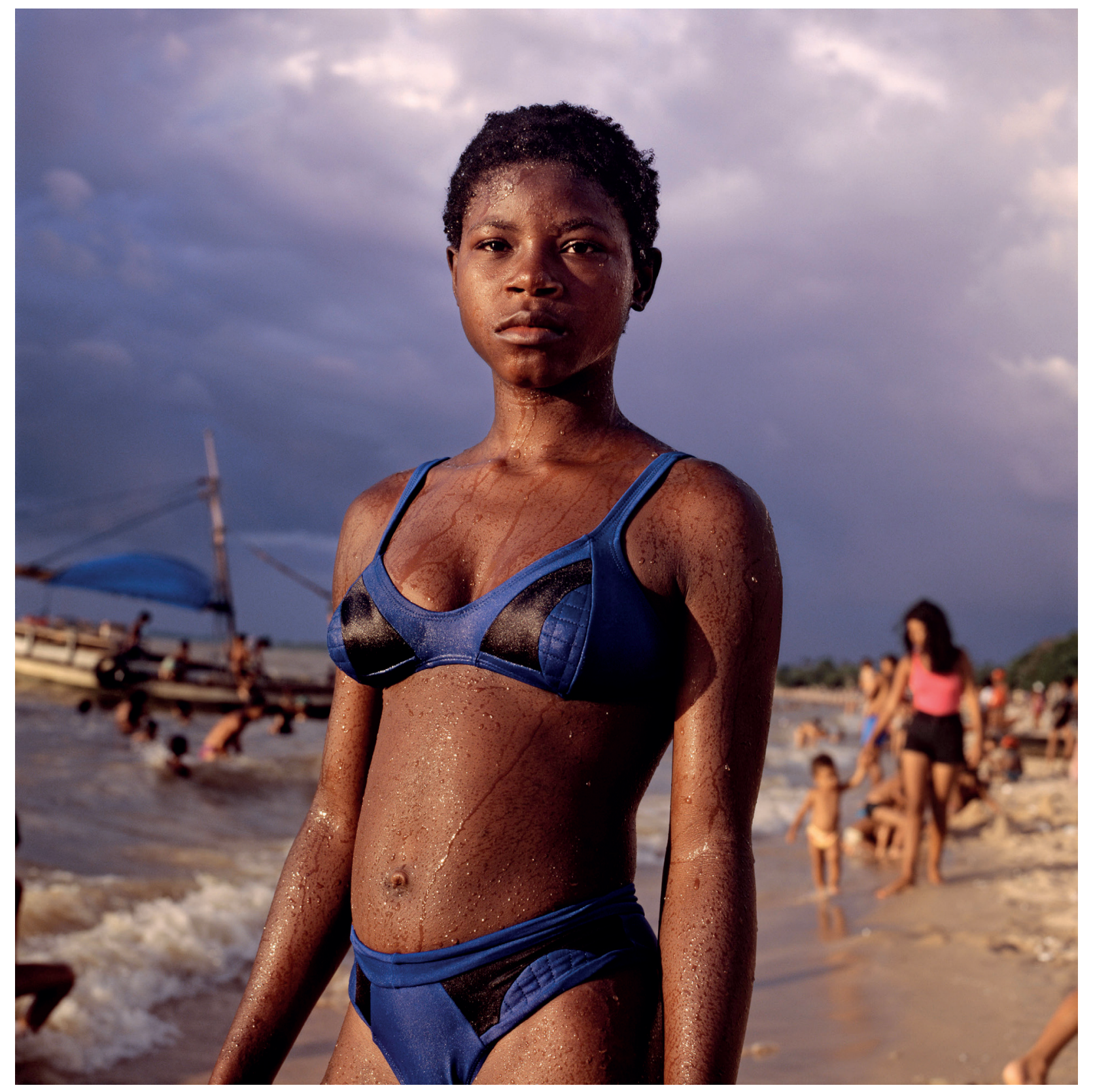

Banhista,

1996 

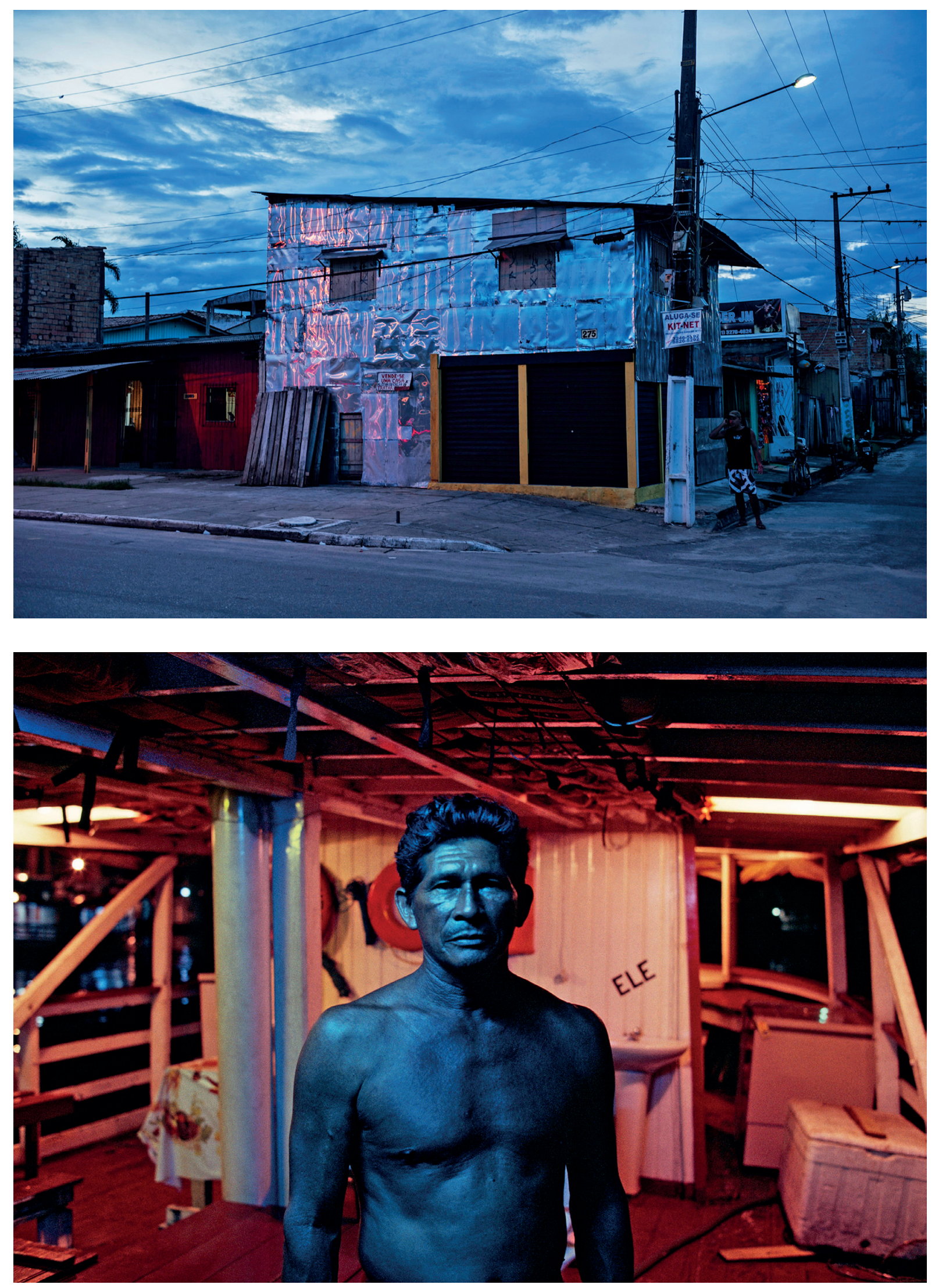

Casa de lata (acima),

2011

Barqueiro azul em Manaus (abaixo),

1992 


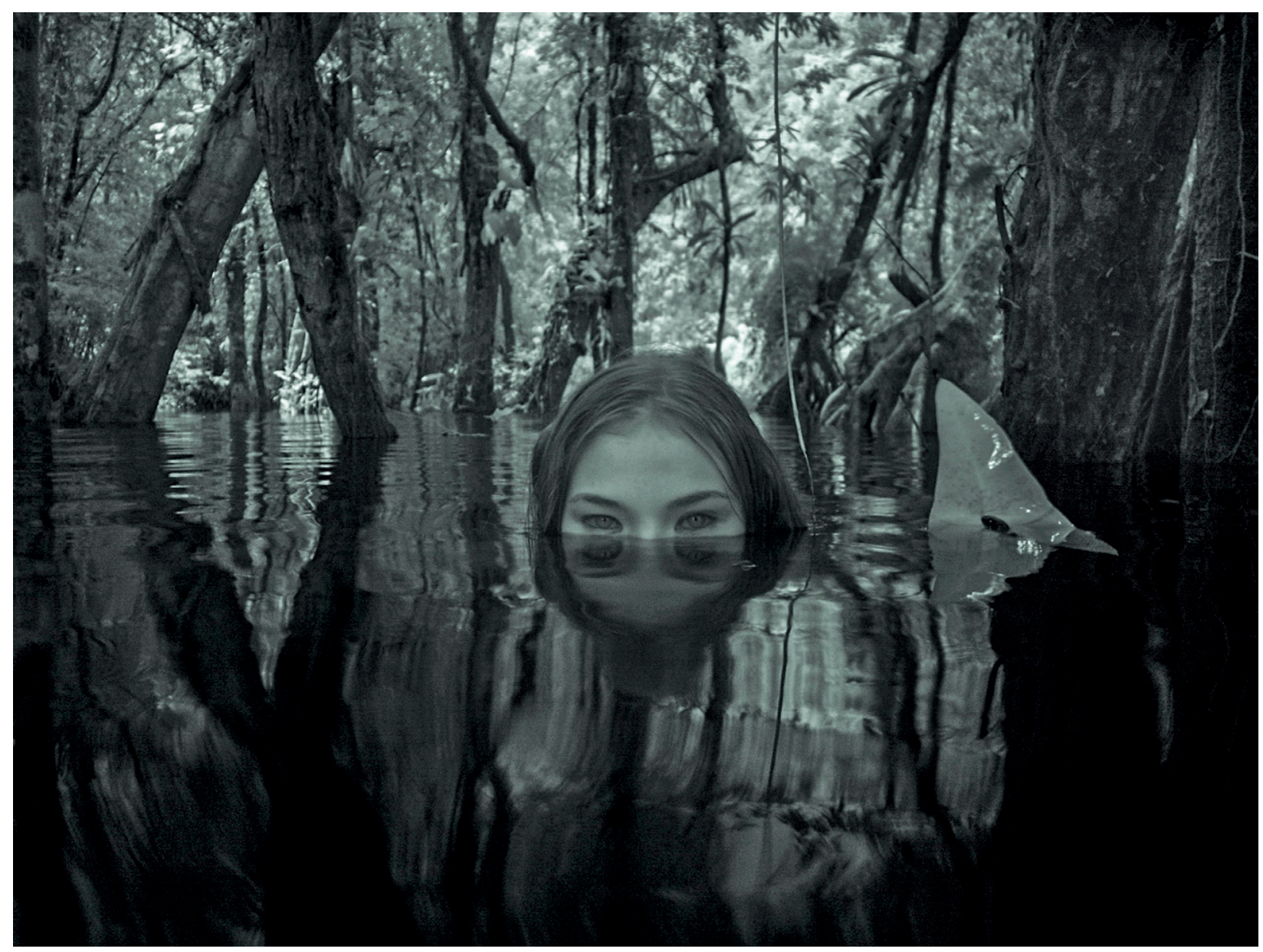

Boiúna,

2011 


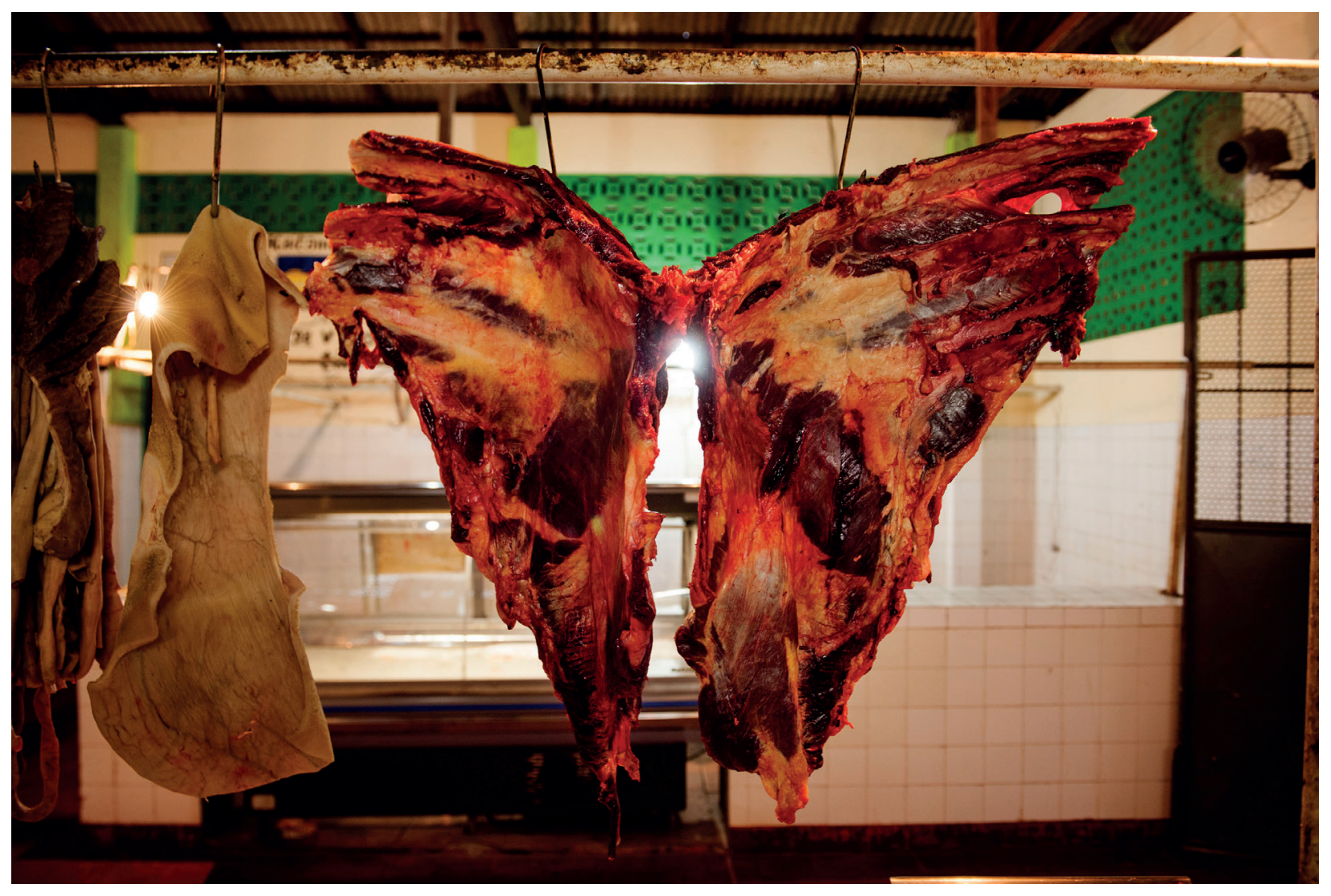

Asas encarnadas,

2014 


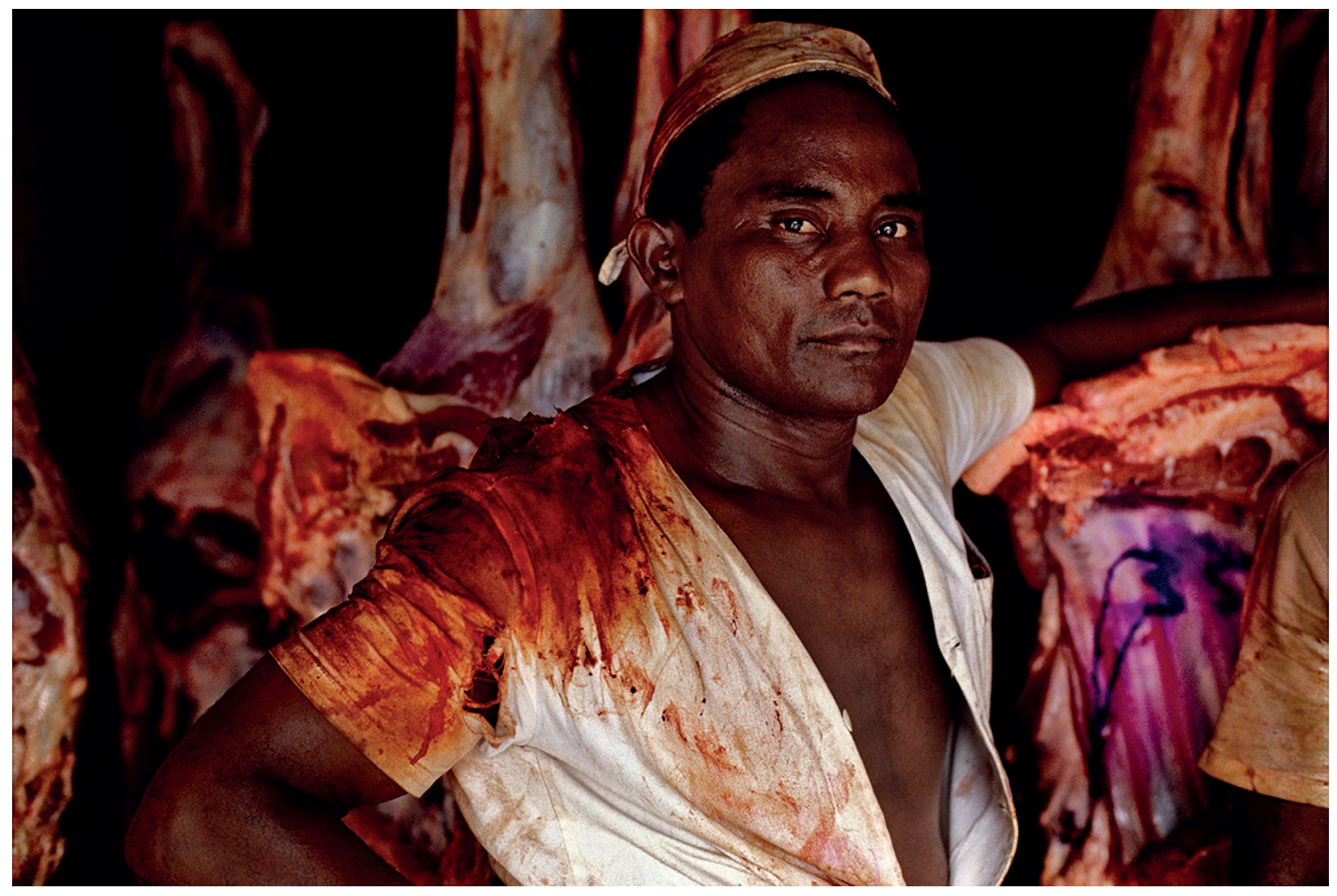

Açougueiro encarnado, 


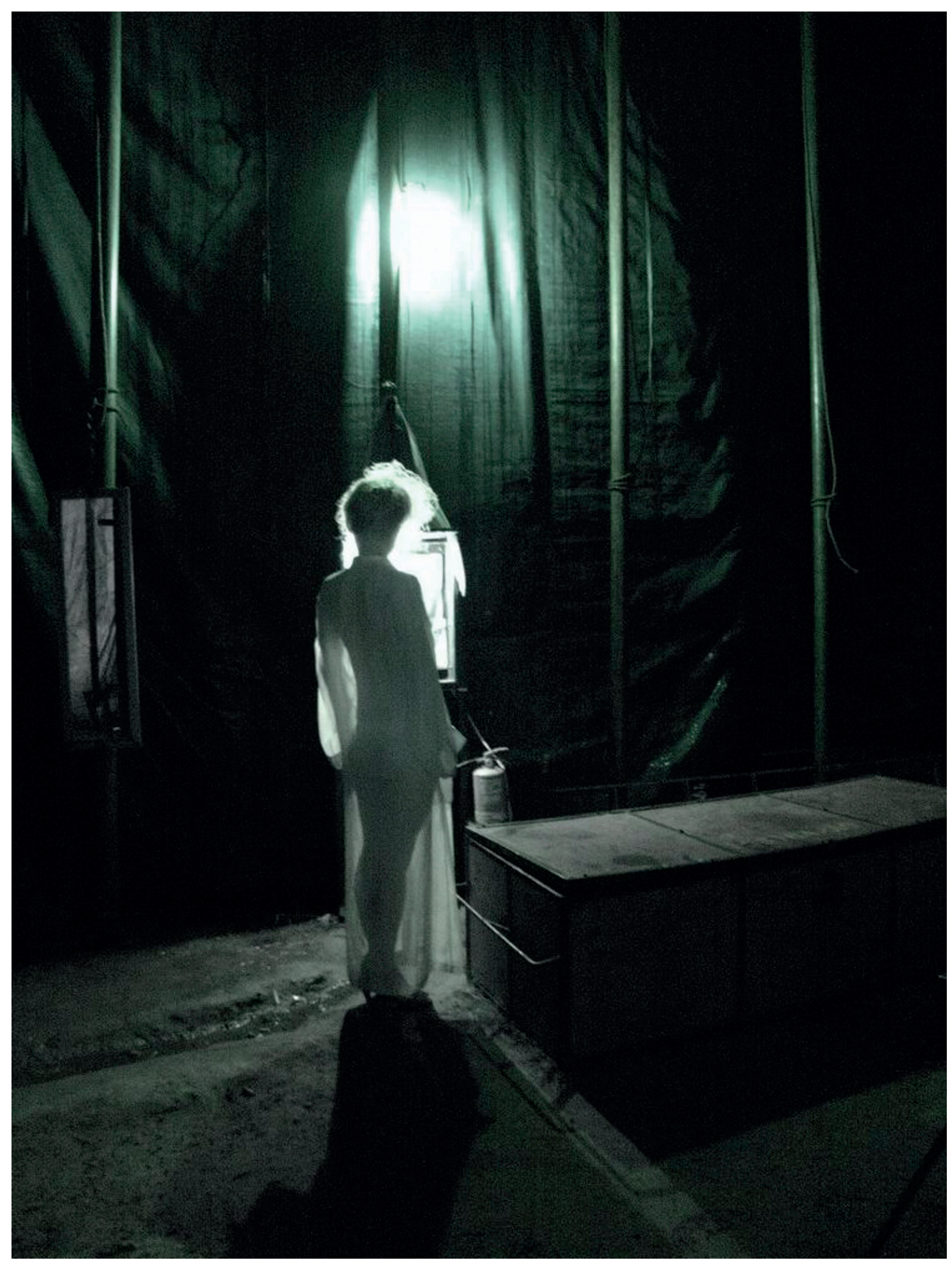

Circo,

2006 


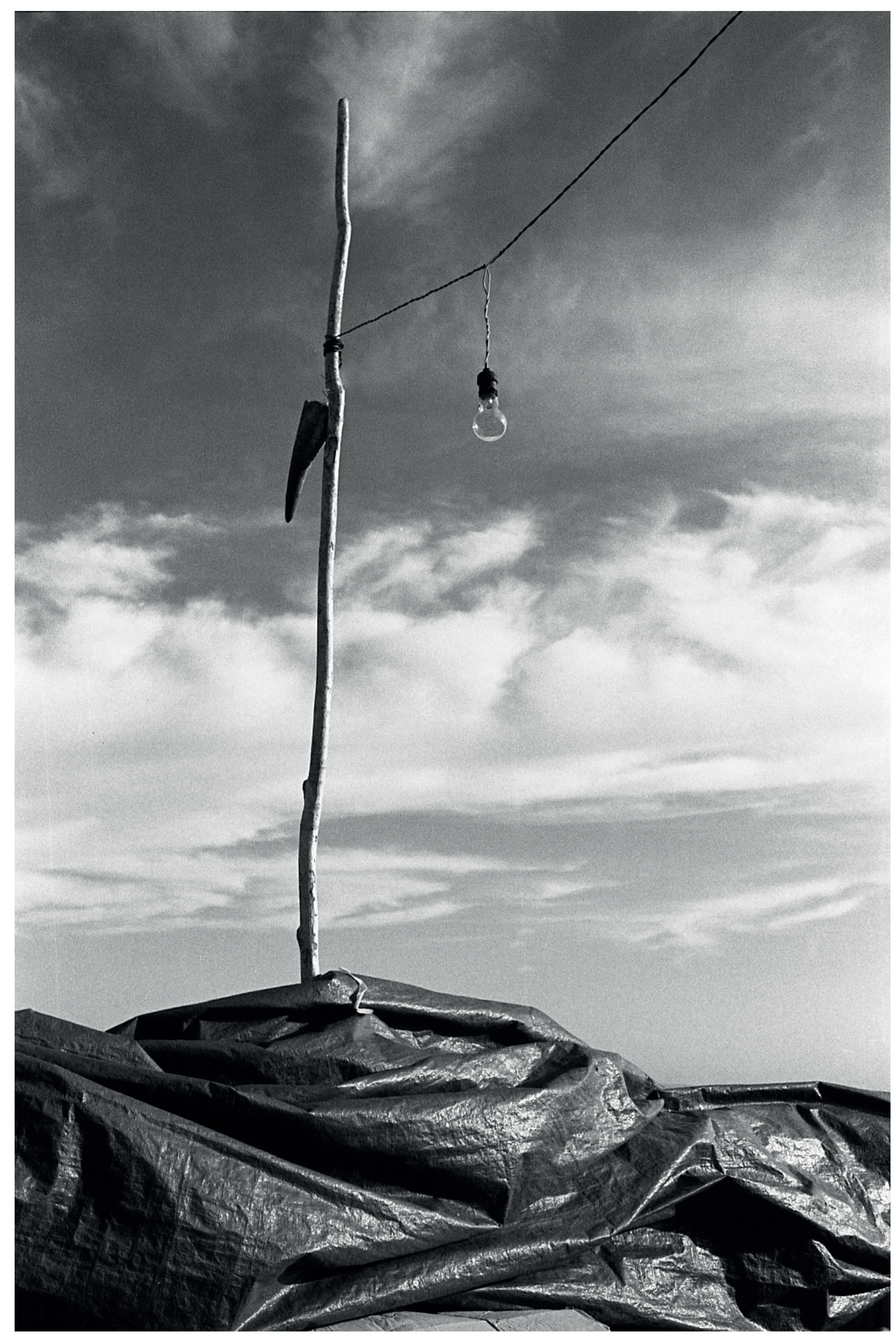




\section{Orlando Maneschy (Texto).}

Pesquisador, artista, curador independente e crítico. Doutor em Comunicação e Semiótica pela PUC-SP. Desenvolveu estágio pós-doutoral na Faculdade de Belas Artes da Universidade de Lisboa. É professor na Universidade Federal do Pará, atuando na graduação e pós-graduação. Coordenador do grupo de pesquisas Bordas Diluídas (UFPA/CNPq). É articulador do Mirante - Território Móvel, uma plataforma de ação ativa que viabiliza proposições de arte. Curador da Coleção Amazoniana de Arte da UFPA. Como artista tem participado de exposições e projetos no Brasil e no exterior, como: Outra Natureza, Faculdade de Belas Artes da Universidade de Lisboa, 2015; Horizonte Generoso - Uma experiência no Pará, Galeria Luciana Caravello, Rio de Janeiro, 2015; Transborda, Galeria Casa Triângulo, São Paulo, 2015; Triangulações,Pinacoteca UFAL - Maceió, CCBEU - Belém e MAM - Bahia, de set. a nov. 2014; Pororoca: A Amazônia no MAR, Museu de Arte do Rlo de Janeiro, 2014 etc. Recebeu, entre outros prêmios, a Bolsa Funarte de Estímulo à Produção Crítica em Artes (Programa de Bolsas 2008); o Prêmio de Artes Plásticas Marcantonio Vilaça / Prêmio Procultura de Estímulo às Artes Visuais 2010 da Funarte e o Prêmio Conexões Artes Visuais - MINC | Funarte | Petrobras 2012, com os quais estruturou a Coleção Amazoniana de Arte da UFPA, realizando mostras, seminários, site e publicação no Projeto Amazônia, Lugar da Experiência. Realizou, as seguintes curadorias: Projeto Correspondência (plataforma de circulação via arte-postal), 2003-2008; Projeto Arte Pará 2008, 2009 e 2010; Amazônia, a arte, 2010; Contra-Pensamento Selvagem dentro de Caos e Efeito, com Paulo Herkenhoff, Clarissa Diniz e Cayo Honorato, 2011; Projeto Amazônia, Lugar da Experiência, 2012, dentre outras.

\section{Luiz Braga (Portfólio).}

Luiz Braga (1956) nasceu, vive e trabalha em Belém (Pa). Graduou-se em Arquitetura, mas nunca exerceu. Fotógrafo desde 1975, suas primeiras exposições eram compostas de cenas de dança, nus, arquitetura e retratos. Em 1981, descobre as cores vibrantes da visualidade popular da Amazônia e viaja pela região aprofundando sua pesquisa sobre a cultura da periferia. Sua abordagem passa ao largo das visões estereotipadas e superficiais sobre a região e junto com o domínio da cor o transformaram em referência na fotografia brasileira contemporânea. Realizou mais de 200 exposições entre individuais e coletivas no Brasil e no exterior. Suas obras estão presentes em importantes acervos privados e públicos. Em 2009 representou o Brasil na 53( Bienal de Veneza. 